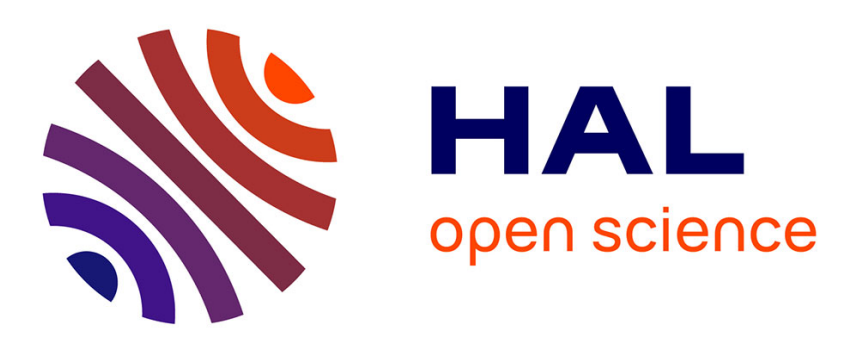

\title{
Characterization of nanomedicines' surface coverage using molecular probes and capillary electrophoresis
}

\author{
J.-B. Coty, F. Varenne, A. Benmalek, O. Garsaa, I. Le Potier, M. Taverna, C.
} Smadja, Christine Vauthier

\section{- To cite this version:}

J.-B. Coty, F. Varenne, A. Benmalek, O. Garsaa, I. Le Potier, et al.. Characterization of nanomedicines' surface coverage using molecular probes and capillary electrophoresis. European Journal of Pharmaceutics and Biopharmaceutics, 2018, 130, pp.48-58. 10.1016/j.ejpb.2018.06.014 . hal02359420

\author{
HAL Id: hal-02359420 \\ https://hal.science/hal-02359420
}

Submitted on 12 Nov 2019

HAL is a multi-disciplinary open access archive for the deposit and dissemination of scientific research documents, whether they are published or not. The documents may come from teaching and research institutions in France or abroad, or from public or private research centers.
L'archive ouverte pluridisciplinaire HAL, est destinée au dépôt et à la diffusion de documents scientifiques de niveau recherche, publiés ou non, émanant des établissements d'enseignement et de recherche français ou étrangers, des laboratoires publics ou privés. 


\section{Characterization of nanomedicines' surface coverage using molecular probes and capillary electrophoresis. ${ }^{\ddagger}$}

J-B. Coty ${ }^{a}$, F. Varenne ${ }^{a}$, A. Benmalek ${ }^{b}$, O. Garsaa ${ }^{a}$, I. Le Potiera, M. Taverna ${ }^{a}$, C. Smadja ${ }^{\mathrm{a}}$, C. Vauthier ${ }^{\mathrm{a} *}$

a Institut Galien Paris-Sud, CNRS, Univ. Paris-Sud, University Paris-Saclay, Châtenay-Malabry, France.

${ }^{b}$ Faculty of Pharmacy, University of Paris-Sud, Chatenay Malabry, France

${ }^{\ddagger}$ Electronic supplementary information (ESI) available.

*Correspondence: Dr. Christine Vauthier, CNRS UMR 8612, Institut Galien Paris Sud, Univ. Paris-Sud, Université Paris-Saclay, 5, rue Jean-Baptiste Clément, 92296 Châtenay-Malabry, France. Fax: +33 146835946. E-mail: christine.vauthier@u-psud.fr 

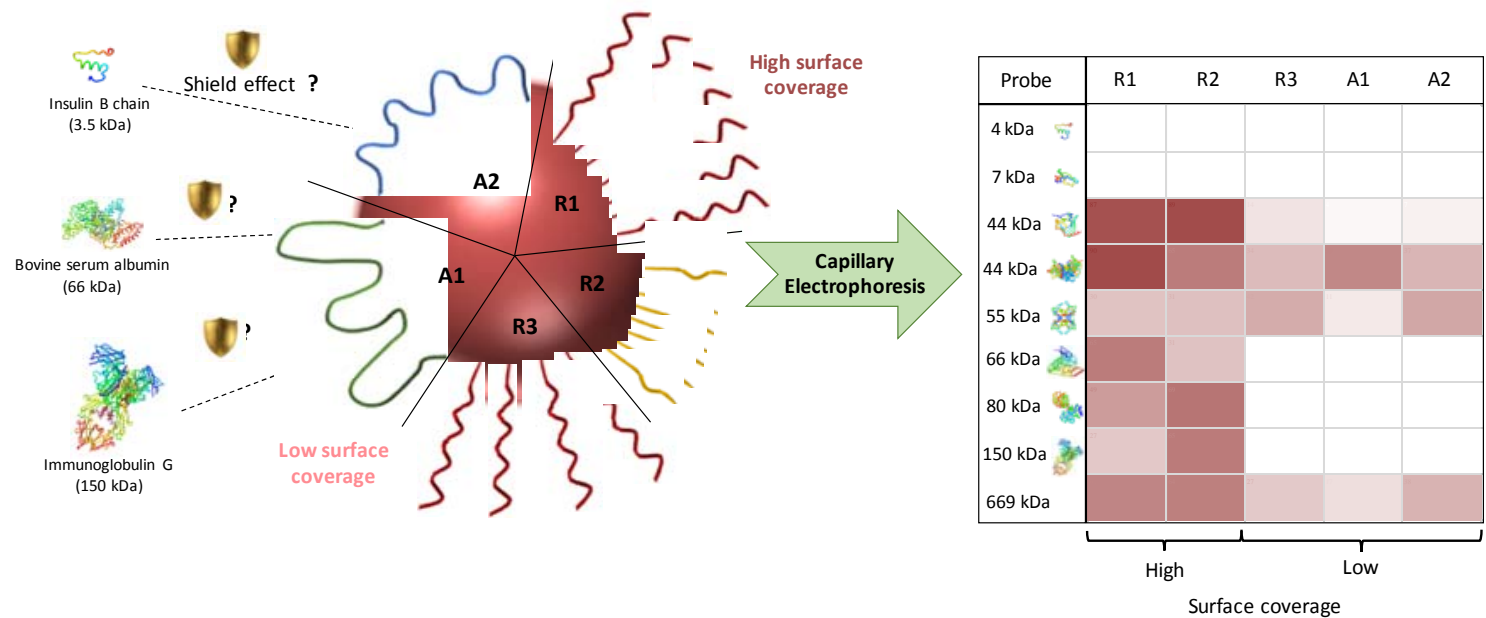

Probing nanomedicines' surface with proteins for routine a characterization of surface coverage by capillary electrophoresis 


\section{Abstract}

A faithful characterization of nanomedicine (NM) is needed for a better understanding of their in vivo outcomes. Size and surface charge are studied with well-established methods. However, other relevant parameters for the understanding of NM behavior in vivo remain largely inaccessible. For instance, the reactive surface of nanomedicines, which are often grafted with macromolecules to decrease their recognition by the immune system, is excluded from a systematic characterization. Yet, it is known that a subtle modification of NM's surface characteristics (grafting density, molecular architecture and conformation of macromolecules) is at the root of major changes in the presence of biological components. In this work, a method that investigates the steric hindrance properties of the NMs' surface coverage based on its capacity to exclude or allow adsorption of well-defined proteins was developed based on capillary electrophoresis. A series of proteins with different molecular weights (MW) were used as molecular probes to screen their adsorption behavior on nanoparticles bearing different molecular architectures at their surface. This novel strategy evaluating to some degree a functionality of NMs can bring additional information about their shell property and might allow for a better perception of their behavior in the presence of biological components. The developed method could discriminate NM with a high surface coverage excluding high MW proteins from NM with a low surface coverage that allowed high MW proteins to adsorb on their surface. The method has the potential for further standardization and automation for a routine use. It can be applied in quality control of NMs and to investigate interactions between proteins and NM in different situations.

Keywords: Nanomedicine, capillary electrophoresis, characterization, surface coverage, molecular probes

\section{Abbreviations:}

CE: capillary electrophoresis; CZE: capillary zone electrophoresis; DLS: dynamic light scattering; ID: immunodiffusion; IE: immunoelectrophoresis; NM: nanomedicine; NP: nanoparticle; PC: principal component; PCA: principal component analysis; PEO: polyethylene oxide; pl: isoelectric point; RC: repellent capacity; SDS: sodium dodecyl sulfate. 


\section{Introduction}

The number of nanoparticle-based medicinal products that have reached clinical development has increased over the last years [1-7]. This is a positive signal acknowledging major general advances of nanomaterials clinical translation. However, several challenges remain unanswered $[2,8-10]$. Among them, the next important step in nanomedicine (NM) development is expected to come from the comprehension of their interactions with biological components encountered in vivo [11]. On this purpose, preliminary efforts are needed to improve the physicochemical characterization of nanomaterials. Indeed, incomplete or inappropriate characterization of important NMs' parameters were identified as critical points in project failures by actors involved in the development of NMs [12]. The characterization has been pointed out as a hurdle that delays and still hampers the development of projects involving nanomaterials $[2,11,13-19]$.

Nanomaterials composing NMs include a wide range of components and their intended use suits for many applications considering different routes of administration, hence facing various delivery and safety challenges $[2,20]$. The precise knowledge of NMs' characteristics is an important process in the understanding of their biological activity and safety. This is also needed for quality control analysis to ensure batch to batch consistency of NMs and evaluate nano-similarity in generic version of NMs that has appeared on the market since 2013 [18]. A therapeutic molecule can be characterized from its well-defined signature deduced from its NMR spectra. In contrast, NMs are complex structures resulting from the combination of multiple components. Their functional behavior including their biological activity and safety depends on many parameters that are defined by fine-tuned of chemical and physical traits for each application $[18,21]$. Characterization of these nanomaterials is complex and parameters to evaluate remains the subject of open discussions. They are often decided on a case by case basis from discussion between companies and health authorities' actors [9, 2225].

Today, properties such as size and surface charge are well controlled and validated to ensure batch to batch consistency. On their own, they are not sufficient to warrant NMs' functionality hence in vivo fate reproducibility [19, 26, 27]. A short list proposed by Crist and McNeil [18] 
from the National Characterization Laboratory of the National Institute of Health includes "the level of surface coverage required for optimal biological performance". The notion of surface coverage includes the density, length, architecture and/or conformation of macromolecules grafted on NM's surface. This parameter regulates the way nanomaterials interact with proteins that is a major phenomenon occurring in vivo in biological fluids containing proteins, with a tremendous impact on the functionality and the biological activity of nanomaterials [28-36]. The importance of the understanding of the surface coverage of NMs has also recently been highlighted in a work studying different macromolecular grafting by Bertrand et al [37]. This suggests that characterization methods of the nanomaterial surface coverage should reach the molecular level, degree of precision needed for the intended use. So far, such evaluations require the use of highly specialized methods that are not generally available [12]. To sum up, the characterization of surface properties has been identified to be not optimal. Regulatory agencies emphasized the need for new methods on this purpose $[12,19,23,26,27,38]$.

To answer this yet unaddressed need, the purpose of our work was to develop a method evaluating the surface coverage of nanomedicines that can be implemented in a quality control analytical cascade. Straightforward characterization of the density, architecture and/or conformation of macromolecules grafted on NM's surface and of the thickness formed by the layer would be highly demanding and cannot be envisaged for a routine use. The proposed method was based on an indirect approach investigating repellent capacities of the NM surface coverage to the adsorption of a series of proteins having well-defined size characteristics. In this method, the proteins served as molecular probes to explore the steric exclusion capacity of the NM surface coverage assuming that a part of it is driven by steric hindrance effect due to the surface coverage property [39]. Proteins taken as molecular probes were chosen from several criteria including knowledge on their characteristics (molecular weight, size through their hydrodynamic diameter, conformation) and their availability as affordable marketed compounds at a high purity grade. The principle of the method was based on the evaluation of the adsorption of individual proteins and the establishment of a map of surface adsorption/exclusion assumed to reflect the surface coverage property of the tested NM. The choice of proteins to probe surface properties of NM was also consistent with their key role in mechanisms controlling the in vivo activity of 
these compounds $[37,40,41]$. The proposed method was designed to provide a simple model evaluating NM surface functionality that can be implemented in routine to be used in quality control of NMs. It is noteworthy that the most relevant method to explore the surface properties of NM would certainly consist on the determination of the protein corona that identifies and quantifies all proteins that adsorbed on NM surface after incubation in plasma. The profile of adsorbed proteins deduced from this analysis determines the so called "biological identity" of the nanomaterial [42]. It is very sensitive to the surface coverage properties of the nanomaterial and its determination raised interests to develop predictive models for the in vivo behavior of NMs including their cellular uptake, stability and biodistribution [41, 43-45]. The method would provide a screenshot of what happens after NM's injection into the blood [41, 42, 46-48]. However, currently, methods allowing the establishment of the protein corona are based on the most advanced techniques applied in proteomic analysis using last generation liquid chromatography - mass spectrometry (LC-MS) instruments. A high expertise is also needed to interpret the data $[46,47,49]$. The preparation of samples prior to the proteomic analysis is based on many manipulations that may introduce bias in the determination of the protein corona $[50,51]$. These possibly disturbing steps might be at the root of the major hurdles encountered for a clear correlation of predictive model between synthetic identity, biological identity formed after administration and outcome of NMs. Thus, it is unrealistic to use such a method at a large scale to characterize nanomaterials on a routine basis for now.

The proposed method was designed to include two steps that can be easily implemented into a high throughput and automated analytical method. They included an incubation of the NM with a series of individual protein and the evaluation of the non-adsorbed fraction of the protein using a general analytical method. A challenge was to choose an analytical method that could be applied straightforward on the sample without pretreatment. Capillary electrophoresis (CE) was selected consistently with its growing interest in studies dealing with protein-nanomaterial interactions [52-56]. Thanks to its adaptability to different purposes, it was assumed that it could be applied on samples without pretreatment. Another advantage is the low sample consumption. This paper describes the different steps of the development of the method and reports the evaluation of its potential to discriminate nanoparticles with low and high protein repellent capacity of the surface coverage using a series of 5 polymer 
nanoparticles designed with different densities, conformations and lengths of chains of dextran grafted on their surface [29, 57-59].

\section{Materials and experimental methods}

\section{II.1. Materials}

Reagents and buffer components: Agarose, polyethylene oxide (PEO) (200,000 Da), ammonium hydroxide, hexadimetrine bromide (Polybrene ${ }^{\circledR}$ ), tricine, tris Base (Sigma 7-9 ${ }^{\circledR}$ ), benzoic acid, sodium chloride and sodium dodecyl sulfate (SDS) were purchased from Sigma (Saint-Quentin-Fallavier, France). Hydrochloric acid $1 \mathrm{M}$ and sodium hydroxide $1 \mathrm{M}$ were supplied by Prolabo (Paris, France). Sodium dihydrogenophosphate monohydrate was obtained from Carlo Erba (Val-de-Reuil, France). Calcium lactate, glacial acetic acid, coomassie brilliant blue R-250 were supplied by Thermo Fisher Scientific (Villebon-sur-Yvette, France). Gel-Fix ${ }^{\mathrm{TM}}$ for agarose $(265 \times 150 \mathrm{~mm})$ was obtained from Serva Electrophoresis (Heidelberg, Germany). All chemicals were of reagent grade and used as purchased. Water used during the study was ultrapure water from a MilliQ ${ }^{\circledR}$ system (Merck, Fontenay-sous-bois, France).

Proteins and antibodies: Goat anti-human IgG, apo-transferrin from human plasma, human immunoglobulin $\mathrm{G}$ and transthyretin from human plasma were provided by Merck (Fontenaysous-bois, France) with a purity $>95 \%$. Aprotinin from bovine lung (purity $=80 \%$ ), bovine serum albumin (purity > 96\%), insulin B chain from bovine pancreas (puritiy > 80\%), orosomucoïd from human plasma (purity > 99\%), ovalbumin from chicken egg white (purity > 98\%), thyroglobulin from bovine thyroid (purity > 90\%), fibrinogen fraction I type 1 from human plasma (purity $=66 \%$ ) and rabbit anti-bovine serum albumin were purchased from Sigma (Saint-Quentin-Fallavier, France).

\section{II.2. Experimental methods}

\section{II.2.1. Nanoparticles synthesis and characterization}

Model nanoparticles made of poly-isobutylcyanoacrylate (PIBCA) and dextran were used in this work. Three types of nanoparticles (NPs) were prepared according to the radical redox emulsion polymerization method described by Bertholon et al. (R1, R2 and R3) [57]. Two types of NPs were prepared via anionic emulsion polymerization method (A1 and A2) [57-60]. Aqueous dispersions were obtained after purification by dialysis against water. NPs were then characterized in terms of hydrodynamic diameter, zeta potential, concentration and 
complement activation as previously described $[29,61]$. Characteristics of the NPs are given in table 1.

\section{II.2.2. Sample preparation}

All samples were prepared as follow prior to analysis. The tested protein $(250 \mu \mathrm{g} / \mathrm{mL})$ was incubated with NPs in phosphate buffer (Sodium dihydrogenophosphate monohydrate: $21 \mathrm{mM}$, adjusted to $\mathrm{pH} 7.4$ with ammonium hydroxide). The final volume of incubation was $300 \mu \mathrm{L}$. NPs concentration was expressed in surface area $\left(\mathrm{cm}^{2} / \mathrm{mL}\right)$ and varied from 0 to 6000 $\mathrm{cm}^{2} / \mathrm{mL}$ for the investigation of adsorption trends. The concentration of NPs was then fixed at $2000 \mathrm{~cm}^{2} / \mathrm{mL}$ for the shield-effect study. Samples were prepared in Eppendorf ${ }^{\circledR}$ Protein LoBind tubes of $0.5 \mathrm{~mL}$ and incubated on a wheel at $30 \mathrm{rpm}$ for $2 \mathrm{~h} 30 \mathrm{~min}$ at $25^{\circ} \mathrm{C}$ (room temperature). At the end of the incubation, the sample was immediately analyzed by capillary zone electrophoresis (CZE) or gel immunoprecipitation. The absence of aggregates was studied by optical microscopy (microscope Olympus $\mathrm{BH}-2$, magnification $\mathrm{x} 40$ ) and dynamic light scattering (DLS) (ZetaSizer Nano ZS 90, Malvern Instruments, Orsay, France) through the measurement of NPs' size and the autocorrelation function profile.

\section{II.2.3. Sample analysis}

\section{II.2.3.1. Capillary zone electrophoresis analysis}

A CE P/ACE MDQ system equipped with an UV detector (Sciex, CA, USA) was used to perform all the CZE experiments. Peak analysis was performed with 32 Karat software. Free proteins were detected and quantified by capillary electrophoresis using a UV detector at $200 \mathrm{~nm}$. Analysis were performed in a $50 \mathrm{~cm}$ (effective length) Polymicro Technologies ${ }^{\mathrm{TM}}$ fused silica capillary, $50 \mu \mathrm{m}$ id x $360 \mu \mathrm{m}$ od, from Molex (Bièvres, France). Three methods were used depending on the isoelectric point ( $\mathrm{pl}$ ) of the protein. These methods are detailed in table 2.

CE electrolyte was Sodium dihydrogenophosphate monohydrate ( $21 \mathrm{mM}$ in water), adjusted to $\mathrm{pH} 7.4$ with ammonium hydroxide or $\mathrm{pH} 3$ with sodium hydrochloride depending on the method used. PEO coating was prepared at $2 \mathrm{mg} / \mathrm{mL}$ in hydrochloric acid at $0.1 \mathrm{M}$. Polybrene ${ }^{\circledR}$ was prepared at $2 \mathrm{mg} / \mathrm{mL}$ in water. At the end of each day of analysis, the capillary was rinsed at 20 psi successively with $\mathrm{NaOH} 0.1 \mathrm{M}$ (10 min) and water (20 min). Benzoic acid at $1 \mathrm{mg} / \mathrm{mL}$ in water was used as migration marker in method 1. 


\section{II.2.3.2. Gel immunoprecipitation}

Rocket immunoelectrophoresis (IE) [62] was used to study BSA adsorption on NPs. Briefly, 13 $\mathrm{mL}$ of $1 \%$ agarose gel containing Rabbit anti-bovine serum albumin $(0.07 \mathrm{mg} / \mathrm{mL})$ and prepared with tricine buffer as described previously [61] was casted at $50^{\circ} \mathrm{C}$ on a $10 \times 7 \mathrm{~cm}$ Gel-Fix ${ }^{\mathrm{TM}}$ film. 19 wells were formed and $5 \mu \mathrm{L}$ of incubated samples were deposited. Calibration samples ranging from $25 \mu \mathrm{g} / \mathrm{mL}$ to $250 \mu \mathrm{g} / \mathrm{mL}$ of BSA were also deposited on each gel. They were submitted to electrophoresis (12 mA, $500 \mathrm{~V})$ for 16 hours.

Radial immunodiffusion (ID) [63] was used to evaluate IgG adsorption on NPs. $11 \mathrm{~mL}$ of $0.7 \%$ agarose gel made in tricine buffer previously mentioned containing Goat anti-Human IgG (10 $\mu \mathrm{L})$ was casted at $50^{\circ} \mathrm{C}$ on a $8 \times 10 \mathrm{~cm} \mathrm{Gel-Fix}{ }^{\mathrm{TM}}$ film. 20 wells were formed and $5 \mu \mathrm{L}$ of incubated samples were deposited. Calibration samples ranging from $25 \mu \mathrm{g} / \mathrm{mL}$ to $250 \mu \mathrm{g} / \mathrm{mL}$ of IgG were also deposited on each gel. They were left for migration in a humid chamber for 24 hours before drying and staining steps.

Gels were dried and stained with coomassie brilliant blue as described previously [46]. Then, they were scanned and processed with ImageJ.

\section{II.2.4. Data treatment and method precision}

The amount of adsorbed protein onto NPs was deduced from the determination of free protein fraction remaining in the sample after incubation. Protein adsorption was thus monitored via the decrease of the free protein amount in the medium. This corresponded to the area of the protein peak detected by CE-UV, to the height of the rocket for rocket IE and to the area of the circle of diffusion obtained from Radial ID. \%ads, the \% of adsorbed protein was then calculated as described in Eq.1:

$\%$ ads $=\frac{(\text { Acontrol }- \text { Asample })}{\text { Acontrol }} * 100 \quad$ (Eq.1)

with $\mathrm{A}_{\text {control }}$ corresponding to the value of area (or height) obtained for the protein injected at $250 \mu \mathrm{g} / \mathrm{mL}$ after $2 \mathrm{~h} 30 \mathrm{~min}$ of incubation without NPs and $A_{\text {sample }}$ the value obtained for the protein detected in the tested sample after incubation with NPs.

The linearity of response to protein detection was assessed by a calibration curve established for each capillary coating (PEO and Polybrene ${ }^{\circledR}$ ) using BSA and IgG respectively. The protein concentration of the calibration curves ranged from $25 \mu \mathrm{g} / \mathrm{mL}$ to $250 \mu \mathrm{g} / \mathrm{mL}(25,50,100,150$, 
200 and $250 \mu \mathrm{g} / \mathrm{mL})$. The linearity was evaluated in terms of correlation coefficient $\left(R^{2}\right)$ of the calibration curves. The precision of the CE methods was tested in terms of detection and quantification of proteins. Repeated injection of BSA and IgG at $250 \mu \mathrm{g} / \mathrm{mL}$ were made in order to evaluate their inter-day (intermediate precision) and intra-day (repeatability) variations. These parameters were evaluated through relative standards variations (RSDs) of the area and migration times of protein peaks. Due to the similarity between methods 2 and 3 , the results of performance of IgG obtained for method 2 were acknowledged to account for method 3 too.

\section{II.2.5. Principal component analysis}

A principal component analysis (PCA) was carried out using SAS 9.4 and JMP Pro 13. A total of 11 variables measured for the different types of NPs were used for this analysis (\% of adsorption of the nine proteins, size and zeta potential). The resolving power of the developed CE method to characterize different surface coverages was graphically evaluated by a biplot representation of the PCA, considering the explained variance (sum of eigenvalues).

\section{Results}

\section{III.1. Development of the method}

\section{III.1.1. Methods' performance}

CE methods were developed to study the adsorption of 9 different proteins onto NPs, evaluating the capacity of the NPs to repel or allow adsorption of these proteins based on shield properties of their surface coverage. This part aimed to demonstrate (i) the methods suitability to separate the fraction of free protein from NPs contained in the sample as well as (ii) the linearity of response as the function of protein concentration and (iii) the ability to perform a precise quantification of the free proteins.

(i) CE conditions to achieve a separation between free proteins and NPs were adapted according to the $\mathrm{pl}$ of the proteins, which determined their charge relatively to the $\mathrm{pH}$ of the CE electrolyte. Three methods were needed to separate free proteins from NPs, considering the 9 proteins probes used in this work. The behavior of the NPs observed in the different methods, i.e. migration of NPs before or after the protein peak, could be explained by the different coatings used in the capillary. 
Method 1: For negatively charged proteins at working conditions ( $\mathrm{pl}$ of the protein < 7: insulin B chain, orosomucoïd, ovalbumin, transthyretin (TTR), BSA, apo-transferin and thyroglobulin), a neutral coating of PEO was used in order to limit adsorption of proteins on the bare silica capillary wall. This led to a negligible electroosmotic flow (EOF) (near zero) and a migration depending mainly on the electrophoretic mobility of the entities ( $\left.\mu_{\mathrm{EP}}\right)$ [64] (Fig. 1B and 1C, left). This explained the migration of proteins towards the anode (positive pole) while NPs were only flushed during the washing step due to their negligible $\mu_{E P}$ value (Fig. $1 \mathrm{~A} \mathrm{left).}$

Methods 2 and 3: For positively charged proteins analysis (aprotinin and $\operatorname{lgG}$ ), a cationic coating of Polybrene ${ }^{\circledR}$ was used (Fig. 1B, right). Electrophoretic mobility of positive proteins was directed to the cathode (negative pole) and the electroosmotic flow was directed to the anode (positive pole), reducing thereby the migration time of the proteins (Fig. 1C, right). It also allowed a separation between NPs and proteins which migrate slower to the anode (Fig. 1A, right).

CE conditions were related to the pl of the protein as described in table 2 .

(ii) The linearity of protein quantification was assessed by calibration curves performed using BSA (method 1) and IgG (methods 2 and 3 ) as model proteins for the two types of coating. Calibration points were measured at 25, 50, 100, 150, 200 and $250 \mu \mathrm{g} / \mathrm{mL}$ for both proteins. Good correlation coefficients of calibration curves were obtained for both proteins using protein peak area $\left(R^{2}=0.998\right.$ for $B S A ; R^{2}=0.995$ for $\left.\lg G\right)$.

(iii) The inter-day fidelity and intra-day repeatability of the methods were tested by measurements of protein areas and migration times for BSA and IgG. Results shown in figure 1D indicated good RSDs for the different methods. As an example, for area measurement, the RSDs obtained for inter-day fidelity were $7.2 \%$ and $4.7 \%$ for BSA and IgG respectively. RSDs obtained for intra-day repeatability injections were $5.0 \%$ and $5.1 \%$ for BSA and IgG respectively.

\section{III.1.2. Optimal NP/protein ratio determination}

The purpose of this part was to identify a NP to protein ratio that could be used to characterize the adsorption of a protein onto a NP and suitable to discriminate NPs depending on their surface coverage properties. This ratio should allow for a representative evaluation of NPs' repellent power towards adsorption of the tested protein. This optimal ratio was determined 
from adsorption trends that were investigated with 2 proteins: BSA and IgG. These two proteins were chosen because they displayed two significantly different molecular weights (66 kDa and $150 \mathrm{kDa}$ respectively), giving a first idea of the NPs' response to probes. This choice was also consistent with the development of the method as BSA could be detected with method 1 and IgG with method 2. The study was carried out using increasing concentrations of NPs (expressed in $\mathrm{cm}^{2} / \mathrm{mL}$ ) incubated with a constant concentration of protein $(250 \mu \mathrm{g} / \mathrm{mL})$. The percentage of adsorbed protein as a function of the surface of NPs present in the incubation medium was determined using the corresponding CE method. The adsorption profile of the 2 proteins was investigated on the five NPs.

A strong adsorption of both BSA and IgG was observed on NPs A1, A2 and R3 (cf. Fig.2 left part). The results highlighted that a surface concentration of $2000 \mathrm{~cm}^{2} / \mathrm{mL}$ of NPs was enough to adsorb almost all proteins present in the incubation medium while the adsorption of the protein on NPs R1 and R2 was much lower. For the latter, the adsorption was not proportional to the amount of NP introduced. For instance, with NPs R1, the amount of IgG adsorbed increased until it reached a plateau near $60 \%$ of adsorption whatever the amount of NP present in the sample. Therefore, we performed experiments with a NP surface concentration of $2000 \mathrm{~cm}^{2} / \mathrm{mL}$ and protein at $250 \mu \mathrm{g} / \mathrm{mL}$. The obtained results allowed a first ranking of the NPs into two groups. One with a high protein adsorption onto NPs (A1, A2 and R3) and another group that seems to exclude the studied proteins (R1 and R2).

Results and conclusions drawn from determinations achieved using the CE methods were confirmed by performing protein determinations using rocket gel electrophoresis according to Laurell's rocket IE method for BSA and by Mancini's radial ID for IgG. Results were depicted in figure 2 (right part). An example of analysis with each gel method was presented in supplementary information (S1 and S2). The consistency of the results obtained from the different methods used to evaluate the free fraction of proteins suggested that the high voltage applied in CE did not introduce any bias.

\section{III.2. Application of the method to evaluate surface coverage of NMs through the shield-effect towards protein adsorption}

The adsorption of 9 proteins was tested on the five NPs. The main properties of the proteins selected to probe properties of the nanoparticle surface coverage were reported in table 3. They mainly differed from their size, charge, overall hydrophobicity and only slightly from their 
shape which was generally globular. Adsorption of these proteins was studied incubating 250 $\mu \mathrm{g} / \mathrm{mL}$ of protein with $2000 \mathrm{~cm}^{2} / \mathrm{mL}$ of NP as previously determined to discriminate NPs allowing high or low adsorption of a given protein. Direct visual observation and optical microscopy confirmed that neither protein nor NP aggregation occurred during incubation. Additionally, size obtained by DLS as well as autocorrelation curves showed no traces of aggregation in samples after incubation (example of data shown in supplementary information S3).

Raw data giving the percentage of adsorption of each protein on the different NPs were plotted on figure 3A. Typically, small proteins massively adsorbed on all types of NPs (Insulin chain B, aprotinin). Adsorption of medium sized proteins (from $44 \mathrm{kDa}$ to $55 \mathrm{kDa}$ ) on the five types of NPs was generally low. A marked difference in the adsorption behavior of proteins on the 5 types of NPs can be highlighted with proteins of the larger size (apo-transferrin, IgG, thyroglobulin). These proteins were totally adsorbed on NPs A1, A2 and R3 while they showed only a low adsorption on NPs R1 and R2 suggesting that they were repelled from the surface of these NPs. These results were emphasized from the adsorption heatmap drawn from the raw data where dark blue represents a strong adsorption (Fig. 3B). This representation clearly emphasizes the difference of behavior between A1, A2, R3 NPs and R1, R2 NPs, showing a global decreased adsorption on R1 and R2. Results were consistent with those that could be expected considering the difference in the architecture and density of the dextran chains grafted on the surface of the NPs used as models in the present study. Radical redox polymerized NPs (especially R1, R2) showed a lower adsorption profile than anionic polymerized NPs ( $\mathrm{A} 1$ and $\mathrm{A} 2$ ). The influence of the density of grafting was also revealed by the difference of adsorption observes between R1 (dense brush 1.3\%) and R3 (loose brush 0.5\%). Adsorption data were then expressed as the NPs' surface area non-accessible to protein. It was called percentage of repellent capacity $\left(\%_{\mathrm{RC}}\right)$. This is in fact the part of the NP where the repellent capacity $(\mathrm{RC})$ is enough to prevent the accessibility of a given protein. All results of RC obtained allowed to conclude about a global degree of surface coverage of the considered NP. On this purpose, the number of adsorbed protein molecules ( $\left.N_{\text {prot }}\right)$ was first deduced from the $\%$ of protein adsorbed (\%ads) thanks to the following equation.

$$
\mathrm{N}_{\text {prot }}=\frac{\% \text { ads } * \text { Cprot } * \text { Vsample* } \mathrm{N}_{\mathrm{A}}}{100 * \mathrm{MW}}(\text { Eq. 2) }
$$


where $C_{\text {prot }}$ is the initial protein concentration (in $\mathrm{g} / \mathrm{L}$ ), $\mathrm{V}_{\text {sample }}$ is the total volume of sample (L), $\mathrm{N}_{\mathrm{A}}$ is the Avogadro constant $\left(\mathrm{N}_{\mathrm{A}}=6.022140857^{*} 10^{23} \mathrm{~mol}^{-1}\right)$ and $\mathrm{MW}$ the molecular weight of the considered protein $(\mathrm{g} / \mathrm{mol})$.

Then, the estimated surface area occupied by these adsorbed protein molecules $\left(\mathrm{S}_{\text {prot, }}\right.$ in $\left.\mathrm{nm}^{2}\right)$ was calculated using the hydrodynamic diameter of the molecules depicted in table 3 (Dh, in $\mathrm{nm})$ :

$\mathrm{S}_{\text {prot }}=\mathrm{Nprot} * 4 * \pi *\left(\frac{D h}{2}\right)^{2} \quad(E q .3)$

From this value obtained in Eq.3, \%RC was calculated:

$\% \mathrm{RC}=\left(1-\frac{\text { Sprot }}{S_{N P}}\right) * 100^{+} \quad(E q .4)$

with $\mathrm{S}_{\mathrm{NP}}$ the total surface area of NPs in the incubation medium $\left(\mathrm{nm}^{2}\right) . \mathrm{S}_{\mathrm{NP}}$ was calculated from the number of NPs in the medium and their hydrodynamic radius, as described in a previous work. $^{46}$

${ }^{+}$when $\mathrm{S}_{\text {prot }}>\mathrm{S}_{\mathrm{NP}}$, \% ${ }_{\mathrm{RC}}$ was set by default to $0 \%$. This case corresponded to a possible multilayer adsorption of proteins on the NP surface.

The $\%$ of repellent capacity was plotted on figure $4 \mathrm{~A}$ with the corresponding heatmap presented on figure 4B. Although no difference between the NPs can be depicted from the data obtained with the smallest proteins (Insulin B chain and aprotinin) that could fully cover the surface of all NPs, a very clear difference in repellent capacity can be highlighted from the data of the adsorption of the larger proteins ( $M W>44 \mathrm{kDa}$ ). The heatmap clearly depicts a series of NPs keeping a surface area non-accessible upon incubation with large proteins (R1 and R2), whereas the other NPs showed a high tendency to be almost fully covered with large proteins.

\section{III.3. Principal component analysis of protein adsorption}

A PCA was performed from the data of adsorption of the nine protein probes on the five NPs, the size and zeta potential of NPs (see Supplementary information, Table S4). The aim was to characterize nanoparticle surface with regard to their adsorption of the nine proteins. In this study, only the characteristics that could be obtained in routine were taken into account, i.e. the size and potential zeta of NPs, combined with the newly determined \% adsorption of the 
nine proteins. Data of adsorption were expressed through new orthogonal variables called principal components (PC). The first two principal components could explain $74 \%$ of the variance (cf Fig. 5A). The pattern of similarity was then depicted on a biplot (cf Fig. 5B). In this plot, the five NPs were placed according to coordinates on PC1 and PC2. We could distinguish two main groups of NPs again with the PCA. NPs R1 and R2 were clearly negatively correlated with PC1, while NPs A1, A2 and R3 were positively correlated to it. As pointed out in the biplot, PC1 is mainly dependent on the \% of adsorption of most proteins, which seems to be discriminant for NP characterization in our study. This is the first time that a method was able to provide a direct information on the capacity of a NM surface to repel a series of proteins.

Then, we can distinguish according to PC2 a difference between NPs A1, A2, R2 and R1, R3. This component is mainly driven by the size of NP and the tendency to adsorb aprotinin, which is globally weak but surprisingly a bit higher for NPs R1 and R3. These data confirmed that size and surface curvature are not sufficient by themselves to explain adsorption of proteins. However, the macromolecular grafting appears to be decisive for such interactions. This ACP study confirmed the ability of the proposed method to characterize NP surface coverage by studying their capacity to prevent adsorption of protein probes.

\section{Discussion}

A CE method was developed to quantify the amount of free protein in samples incubated with NPs to evaluate a new parameter characterizing NMs' surface, the surface coverage. In some degree, this parameter is a measure of the functional behavior of NMs. The method is based on studying adsorption of a series of well define proteins on NMs using standardized conditions assuming that adsorption is allowed or hindered depending on NMs' surface coverage property. The map drawn from the adsorption fate of each protein of the series was assumed to provide with an objective evaluation of the nanoparticle surface property regarding its interactions with proteins. This method was developed to answer the need for new methods of characterization of NMs' surface. Choices, including the use of $\mathrm{CE}$, were made to provide with a method that could be easily implemented for routine analysis. In general, the mode of CE to be used to perform analysis is chosen depending on the kinetics of the studied interaction, here interactions leading to protein adsorption onto NPs. Fast association- 
dissociation systems are studied by affinity capillary electrophoresis (ACE), Hummel Dreyer method, or frontal analysis capillary electrophoresis (FACE). On the contrary, slow kinetics of interactions are studied via capillary zone electrophoresis (CZE) or FACE $[52,54,56]$. In our model, determination of the amount of free protein remaining in the sample was achieved after incubation with NPs during $2 \mathrm{~h} 30 \mathrm{~min}$ to reach the equilibrium, according to a slow kinetics of interactions. CZE was then selected using the non-equilibrium capillary electrophoresis of equilibrium mixtures (NECEEM) [65]. This mode is easy-to-use and allows protein quantification directly from the evaluation of the peak area. The technique presents other advantages: (i) a low consumption of sample, (ii) a separation and determination of the amount of free proteins without any need of pre-treatment of the sample which contains both proteins and NPs, and (iii) its automatability.

The optimal duration of incubation was determined through a kinetics study of BSA adsorption onto NPs (data not shown) and was consistent with previous works optimized with these NPs $[39,58,66]$. As the kinetics of association and dissociation were slow and the equilibrium reached after a period of incubation of $2 \mathrm{~h} 30 \mathrm{~min}$, we hypothesized that acidic conditions employed during the short duration of the CE separation in method $2(\mathrm{pH}=3)$ was not detrimental for the equilibrium of adsorption. This assumption was supported by a prior study made on the comparable NP-protein system, where adsorption equilibrium showed no major modification in a short period upon a pH modification [66]. The three methods could be used to investigate the adsorption of nine proteins on five types of NPs used as models. The precision of the method was verified in terms of intra-day and inter-day repeatability. The results included the deviation due to the different preparations of the samples, as a new sample was prepared and incubated for each inter-day determination. It was also verified that the results obtained by CE were not biased due to the high voltage used during analysis. The similar results obtained using two other methods of evaluation of free proteins in the same samples acknowledged that our CE methods could determine the amount of free proteins in samples containing NPs, without need to remove NPs prior to analysis. An optimal ratio between the concentration of protein and NPs was determined from adsorption trends established with two proteins. It was selected in order to discriminate different responses to protein adsorption between NPs. A high surface coverage of NPs allowed a low adsorption profile of proteins while those bearing a low surface coverage allowed a high adsorption of 
proteins. The CE methods were then applied to screen the adsorption of the 9 different selected proteins on the five types of NPs after incubation at the previously selected ratio. The five types of NPs could be classified in two groups based on the obtained raw data of adsorption. The proposed method could discriminate NPs with surfaces accessible to the larger proteins from NPs which surface properties seemed to exclude these proteins. These raw data took into consideration the difference in size between NPs because their concentration was expressed in surface area/mL. However, they did not take into account the difference in size of the proteins. Considering this parameter, the amount of surface occupied by the adsorbed proteins on the NP surface was calculated and in turn the amount of NP surface that remained free of adsorption. This last parameter can be viewed as the repellent capacity of the NP creating an efficient shield-effect against the adsorption of a given protein. The degree of surface coverage was then estimated from the results of repellent capacities obtained with the 9 proteins. We could distinguish NP with a high surface coverage, showing a high repellent capacity for large proteins (NPs R1 and R2). On the contrary, NPs showing a low repellent capacity for most proteins were qualified as bearing a low surface coverage (A1, $A 2$ and $R 3)$.

The difference was confirmed with the data representation of the RC which even emphasized the fact that the surface of NPs A1, A2 and R3 were almost fully accessible to tested proteins whatever their size. These observed behaviors were consistent with the results expected from surface characteristics shown by our model NPs (table 1). The dense brushes present on R1 and $\mathrm{R} 2$ repelled large proteins while loose $\mathrm{R} 3$ brush as well as loops conformations of $\mathrm{A} 1$ and A2 allowed the adsorption of these large proteins. These critical parameters have also been identified in recent studies, were both chain length and density were strongly involved in the steric repulsion of molecules $[30,37]$. It is worth noting that it is impossible to predict NPs behavior with proteins considering current usual parameters assessed in routine, namely NP size and potential zeta. This is illustrated considering NPs R1 and R3. They are very similar in terms of their size and zeta potential (respectively $286 \mathrm{~nm}$ and $-4 \mathrm{mV}$ for R1; $281 \mathrm{~nm}$ and -5 $\mathrm{mV}$ for R3) but the new method has revealed a very different behavior on their surface repellent properties based on protein adsorption evaluation.

Raw results were confronted to a PCA in order to extract a clear view of NPs' ranking as a function of the main components representing the higher part of explained variance. The PCA 
allowed to separate two clusters, distinguishing NPs having a high surface coverage property against NPs with a lower protein repellent power due to their surface architecture. This analysis confirmed the ability of the method to evaluate surface coverage of different NPs in a quality control approach.

These results demonstrated the interest of the present approach to assess a new parameter characterizing a surface property of NMs that is linked to their functional behavior. The method that is based on the simple monitoring of protein adsorption in very well-defined conditions can be further standardized. It can also be fully automatable being a suitable candidate to be used in quality control.

\section{Conclusion}

The method developed in the present work provides a tool to access a new characteristic of a $\mathrm{NM}$, its surface coverage property. This parameter is critical for the functionality of the NM as it controls protein adsorption phenomena that define in vivo fate, activity and safety. The use of CE allows direct analysis of samples without pre-treatment steps. The method can be standardized. It is based on well-established experimental conditions and uses molecular probes that are marketed as pure proteins. Being automatable, this CE method is also attractive for a systematic analysis of NMs. Results produced by this method could be of paramount interest in the future as analytical method to perform quality control analysis of NMs. Besides, the method can be used to set up models to study various phenomena linked to protein adsorption on NMs. For instance, competitions between proteins during adsorption could be studied adding more than one protein in the incubation medium. Capacity of one protein to displace another already adsorbed on the surface of NM could also be assessed setting up appropriate experimental conditions of sample preparation. The method is suitable to investigate these phenomena including their kinetic aspects. Overall, the method developed in this work proves the potential for assessing key properties of NP surface functionality linked to its molecular design that could not be characterized so far.

\section{Conflicts of interest}

There are no conflicts to declare. 


\section{Acknowledgements}

Funding: This work was supported by BPI-France, Project NICE.

\section{Bibliography}

1. Anselmo, A. C. \& Mitragotri, S. Nanoparticles in the clinic: Nanoparticles in the Clinic. Bioengineering \& Translational Medicine 1, 10-29 (2016).

2. Finch, G., Havel, H., Analoui, M., Barton, R. W., Diwan, A. R., Hennessy, M., Reddy, V., Sadrieh, N., Tamarkin, L., Wolfgang, M., Yerxa, B., Zolnik, B. \& Liu, M. Nanomedicine Drug Development: A Scientific Symposium Entitled 'Charting a Roadmap to Commercialization'. The AAPS Journal 16, 698-704 (2014).

3. Bobo, D., Robinson, K. J., Islam, J., Thurecht, K. J. \& Corrie, S. R. Nanoparticle-Based Medicines: A Review of FDA-Approved Materials and Clinical Trials to Date. Pharm Res. 33(10), 2373-87 (2016). doi: 10.1007/s11095-016-1958-5

4. Weissig, V., Pettinger, T. K. \& Murdock, N. Nanopharmaceuticals (part I): products on the market. Int. J. Nanomedicine 9, 4357-4373 (2014).

5. Weissig, V. \& Guzman-Villanueva. Nanopharmaceuticals (part II): Products in the pipeline. Int. J. Nanomedicine 10, 1245-1257 (2015).

6. Xue, H. Y., Liu, S. \& Wong, H. L. Nanotoxicity: a key obstacle to clinical translation of siRNA-based nanomedicine. Nanomedicine, 9, 295-312 (2014).

7. Lee, M. S., Dees, E. C. \& Wang, A. Z. Nanoparticle-delivered chemotherapy: old drugs in new packages. Oncology (Williston Park). 31(3), 198-208 (2017).

8. Agrahari, V. \& Hiremath, P. Challenges associated and approaches for successful translation of nanomedicines into commercial products. Nanomedicine 12, 819-823 (2017).

9. Ragelle, H., Danhier, F., Préat, V., Langer, R. \& Anderson, D. G. Nanoparticle-based drug delivery systems: a commercial and regulatory outlook as the field matures. Expert Opinion on Drug Delivery 14, 851-864 (2017).

10. Landesman-Milo, D. \& Peer, D. Transforming Nanomedicines From Lab Scale Production to Novel Clinical Modality. Bioconjugate Chemistry 27, 855-862 (2016).

11. Halappanavar, S., Vogel, U., Wallin, H. \& Yauk, C. L. Promise and peril in nanomedicine: the challenges and needs for integrated systems biology approaches to define health risk: Systems biology for nanomedicine and nanotoxicology. Wiley Interdisciplinary Reviews: Nanomedicine and Nanobiotechnology e1465 (2017). doi:10.1002/wnan.1465

12. Baer, D. R., Engelhard, M. H., Johnson, G. E., Laskin, J., Lai, J., Mueller, K., Munusamy, P., Thevuthasan, S., Wang, H., Washton, N., Elder, A., Baisch, B. L., Karakoti, A., Kuchibhatla, S. V. N. T. \& Moon, D. Surface characterization of nanomaterials and nanoparticles: Important needs and challenging opportunities. Journal of Vacuum Science \& Technology A: Vacuum, Surfaces, and Films 31, 050820 (2013).

13. Salvador Morales, C., Khorasani, A. A. \& Weaver, J. Closing the gap: accelerating the translational process in nanomedicine by proposing standardized characterization techniques. International Journal of Nanomedicine 5729 (2014). doi:10.2147/IJN.S72479

14. Wei, A., Mehtala, J. G. \& Patri, A. K. Challenges and opportunities in the advancement of nanomedicines. Journal of Controlled Release 164, 236-246 (2012).

15. Shiekh, F. A., Farooq, O., Mian, S. H., Bautista, R. L., Arja, S. B. \& Andrabi, K. I. The pitfalls of growing nanomaterials. Nanomedicine (Lond) 11, 1635-1638 (2016). 
16. Roebben, G., Rasmussen, K., Kestens, V., Linsinger, T. P. J., Rauscher, H., Emons, H. \& Stamm, H. Reference materials and representative test materials: the nanotechnology case. J. Nanopart. Res. 15, 1455 (2013).

17. Coty, J.-B. \& Vauthier, C. Characterization of nanomedicines: A reflection on a field under construction needed for clinical translation success. Journal of Controlled Release 275, 254-268 (2018).

18. Crist, R. \& McNeil, S. Nanotechnology for Treating Cancer: Pitfalls and Bridges on the Path to Nanomedicines, $2015.2 \quad$ https://www.cancer.gov/research/keyinitiatives/ras /rascentral/blog/2015/nanomedicines Consulted on August 2017.

19. Clogston, J. D., Crist, R. M. \& McNeil, S. E. in Polymer Nanoparticles for Nanomedicines: A Guide for their Design, Preparation and Development (eds. Vauthier, C. \& Ponchel, G.) 187-203 (Springer International Publishing, 2016). at <https://doi.org/10.1007/978-3-319-41421-8_7>

20. Nyström, A. M. \& Fadeel, B. Safety assessment of nanomaterials: Implications for nanomedicine. Journal of Controlled Release 161, 403-408 (2012).

21. Fadeel, B., Feliu, N., Vogt, C., Abdelmonem, A. M. \& Parak, W. J. Bridge over troubled waters: understanding the synthetic and biological identities of engineered nanomaterials: Bridging nanotoxicology and nanomedicine. Wiley Interdisciplinary Reviews: Nanomedicine and Nanobiotechnology 5, 111-129 (2013).

22. Xu, X. \& Khan, M. A. in Polymer Nanoparticles for Nanomedicines: A Guide for their Design, Preparation and Development (eds. Vauthier, C. \& Ponchel, G.) 615-633 (Springer International Publishing, 2016). at <https://doi.org/10.1007/978-3-319-41421-8_19>

23. Borgos, S. E. F., Cornier, J., Owen, A., Kwade, A. \& Van de Voorde, M. in Pharmaceutical Nanotechnology: Innovation and Production 135-156 (Wiley-VCH Verlag GmbH \& Co. KGaA, 2017). at <http://dx.doi.org/10.1002/9783527800681.ch7>

24. FDA Nanotechnology Task Force Report 2007 https://www.fda.gov/ScienceResearch/ SpecialTopics/Nanotechnology/ucm2006659.htm Consulted on April 2018.

25. Duncan, R., Nanomedicine(s) and their regulation: an overview. In "Handbook of Safety assessment of nanomaterials: from toxicological assessment to personalized medicine". (Ed. Bengt Fadeel) 1-30 (Pan Standford Publishing, 2015).

26. Gao, X. \& Lowry, G. V., Progress towards standardized and validated characterizations for measuring physicochemical properties of manufactured nanomaterials relevant to nano health and safety risks. Nanolmpact 9, 14-30 (2018).

27. Steinhäuser, K. G. \& Sayre, P. G. Reliability of methods and data for regulatory assessment of nanomaterial risks. Nanolmpact 7, 66-74 (2017)

28. Hamad, I., Al-Hanbali, O., Hunter, A. C., Rutt, K. J., Andresen, T. L. \& Moghimi, S. M. Distinct Polymer Architecture Mediates Switching of Complement Activation Pathways at the Nanosphere-Serum Interface: Implications for Stealth Nanoparticle Engineering. ACS Nano 4, 6629-6638 (2010).

29. Coty, J.-B., Eleamen Oliveira, E. \& Vauthier, C. Tuning complement activation and pathway through controlled molecular architecture of dextran chains in nanoparticle corona. International Journal of Pharmaceutics (2017). doi:10.1016/j.ijpharm.2017.04.048

30. Lin, J., Zhang, H., Morovati, V. \& Dargazany, R. PEGylation on mixed monolayer gold nanoparticles: Effect of grafting density, chain length, and surface curvature. Journal of Colloid and Interface Science 504, 325-333 (2017).

31. Kurtz-Chalot, A., Villiers, C., Pourchez, J., Boudard, D., Martini, M., Marche, P. N., Cottier, M. \& Forest, V. Impact of silica nanoparticle surface chemistry on protein corona formation and consequential interactions with biological cells. Materials Science and Engineering: C 75, 16-24 (2017).

32. Walkey, C. D., Olsen, J. B., Guo, H., Emili, A. \& Chan, W. C. W. Nanoparticle Size and Surface Chemistry Determine Serum Protein Adsorption and Macrophage Uptake. Journal of the American Chemical Society 134, 2139-2147 (2012). 
33. Fornaguera, C., Calderó, G., Mitjans, M., Vinardell, M. P., Solans, C. \& Vauthier, C. Interactions of PLGA nanoparticles with blood components: protein adsorption, coagulation, activation of the complement system and hemolysis studies. Nanoscale 7, 6045-6058 (2015).

34. Saei, A. A., Yazdani, M., Lohse, S. E., Bakhtiary, Z., Serpooshan, V., Ghavami, M., Asadian, M., Mashaghi, S., Dreaden, E. C., Mashaghi, A. \& Mahmoudi M. Nanoparticle Surface Functionality Dictates Cellular and Systemic Toxicity. Chem. Mater. 29, 6578-6595 (2017).

35. Yu, K., Lai, B. F., Foley, J. H., Krisinger, M. J., Conway, E.M. \& Kizhakkedathu, J.N. Modulation of complement activation and amplification on nanoparticle surfaces by glycopolymer conformation and chemistry. ACS Nano. 8(8), 7687-703 (2014). doi: 10.1021/nn504186b.

36. D'Addio, S. M., Saad, W., Ansell, S.M., Squiers, J.J., Adamson, D.H., Herrera-Alonso, M., Wohl, A. R., Hoye, T. R., Macosko, C. W., Mayer, L.D., Vauthier, C. \& Prud'homme, R.K. Effects of block copolymer properties on nanocarrier protection from in vivo clearance. J Control Release 162(1), 208-17 (2012). doi: 10.1016/j.jconrel.2012.06.020.

37. Bertrand, N., Grenier, P., Mahmoudi, M., Lima, E. M., Appel, E. A., Dormont, F., Lim, J.-M., Karnik, R., Langer, R. \& Farokhzad, O. C. Mechanistic understanding of in vivo protein corona formation on polymeric nanoparticles and impact on pharmacokinetics. Nature Communications 8, (2017).

38. EMA Reflection paper on surface coatings: general issues for consideration regarding parenteral $\begin{array}{llll}\text { administration of coated nanomedicine products, } 2013 & \end{array}$ http://www.ema.europa.eu/docs/en GB/document library/Scientific guideline/2013/08/WC50 0147874.pdf Consulted on August 2017.

39. Vauthier, C., Persson, B., Lindner, P. \& Cabane, B. Protein adsorption and complement activation for di-block copolymer nanoparticles. Biomaterials 32, 1646-1656 (2011).

40. Szeto, G.L. \& Lavik, E. B. Materials design at the interface of nanoparticles and innate immunity. J Mater Chem B 4(9), 1610-1618 (2016).

41. O'Connell, D. J., Bombelli, F. B., Pitek, A. S., Monopoli, M. P., Cahill, D. J. \& Dawson, K. A. Characterization of the bionano interface and mapping extrinsic interactions of the corona of nanomaterials. Nanoscale 7, 15268-15276 (2015).

42. Walkey, C. D. \& Chan, W. C. W. Understanding and controlling the interaction of nanomaterials with proteins in a physiological environment. Chemical Society Reviews 41, 2780 (2012).

43. Beck, M., Mandal, T., Buske, C. \& Lindén, M. Serum protein adsorption enhances active leukemia stem cell targeting of mesoporous silica nanoparticles. ACS Applied Materials \& Interfaces (2017). at $<$ http://pubs.acs.org/doi/abs/10.1021/acsami.7b04742>

44. Brun, E. \& Sicard-Roselli, C. Could nanoparticle corona characterization help for biological consequence prediction? Cancer nanotechnology 5, 7 (2014).

45. Schöttler, S., Becker, G., Winzen, S., Steinbach, T., Mohr, K., Landfester, K., Mailänder, V. \& Wurm, F. R. Protein adsorption is required for stealth effect of poly(ethylene glycol)- and poly(phosphoester)-coated nanocarriers. Nature Nanotechnology 11, 372-377 (2016).

46. Walkey, C. D., Olsen, J. B., Song, F., Liu, R., Guo, H., Olsen, D. W. H., Cohen, Y., Emili, A. \& Chan, W. C. W. Protein Corona Fingerprinting Predicts the Cellular Interaction of Gold and Silver Nanoparticles. ACS Nano 8, 2439-2455 (2014).

47. Hadjidemetriou, M., Al-Ahmady, Z., Mazza, M., Collins, R. F., Dawson, K. \& Kostarelos, K. In Vivo Biomolecule Corona around Blood-Circulating, Clinically Used and Antibody-Targeted Lipid Bilayer Nanoscale Vesicles. ACS Nano 9, 8142-8156 (2015).

48. Nguyen, V. H. \& Lee, B.-J. Protein corona: a new approach for nanomedicine design. International Journal of Nanomedicine 12, 3137-3151 (2017).

49. Bigdeli, A., Palchetti, S., Pozzi, D., Hormozi-Nezhad, M. R., Baldelli Bombelli, F., Caracciolo, G. \& Mahmoudi, M. Exploring Cellular Interactions of Liposomes Using Protein Corona Fingerprints and Physicochemical Properties. ACS Nano 10, 3723-3737 (2016).

50. Pisani, C., Gaillard, J. C., Dorandeu, C., Charnay, C., Guari, Y., Chopineau, J., Devoisselle, J. M., Armengaud, J. \& Prat, O. Experimental separation steps influence the protein content of corona around mesoporous silica nanoparticles. Nanoscale 9, 5769-5772 (2017). 
51. Lundqvist, M., Augustsson, C., Lilja, M., Lundkvist, K., Dahlbäck, B., Linse, S. \& Cedervall, T. The nanoparticle protein corona formed in human blood or human blood fractions. PLOS ONE 12, e0175871 (2017).

52. Aleksenko, S. S., Shmykov, A. Y., Oszwałdowski, S. \& Timerbaev, A. R. Interactions of tumourtargeting nanoparticles with proteins: potential of using capillary electrophoresis as a direct probe. Metallomics 4, 1141 (2012).

53. Capriotti, A. L., Caracciolo, G., Cavaliere, C., Colapicchioni, V., Piovesana, S., Pozzi, D. \& Laganà, A. Analytical Methods for Characterizing the Nanoparticle-Protein Corona. Chromatographia 77, 755-769 (2014).

54. Trapiella-Alfonso, L., Ramírez-García, G., d’Orlyé, F. \& Varenne, A. Electromigration separation methodologies for the characterization of nanoparticles and the evaluation of their behaviour in biological systems. TrAC Trends in Analytical Chemistry 84, 121-130 (2016).

55. Li, N., Zeng, S., He, L. \& Zhong, W. Probing Nanoparticle-Protein Interaction by Capillary Electrophoresis. Analytical Chemistry 82, 7460-7466 (2010).

56. Ramírez-García, G., d'Orlyé, F., Gutiérrez-Granados, S., Martínez-Alfaro, M., Mignet, N., Richard, C. \& Varenne, A. Electrokinetic Hummel-Dreyer characterization of nanoparticle-plasma protein corona: The non-specific interactions between PEG-modified persistent luminescence nanoparticles and albumin. Colloids and Surfaces B: Biointerfaces 159, 437-444 (2017).

57. Bertholon, I., Lesieur, S., Labarre, D., Besnard, M. \& Vauthier, C. Characterization of Dextran-Poly(isobutylcyanoacrylate) Copolymers Obtained by Redox Radical and Anionic Emulsion Polymerization. Macromolecules 39, 3559-3567 (2006).

58. Vauthier, C., Lindner, P. \& Cabane, B. Configuration of bovine serum albumin adsorbed on polymer particles with grafted dextran corona. Colloids and Surfaces B: Biointerfaces 69, 207-215 (2009).

59. Vauthier, C. in Biointeractions of Nanomaterials 365-382 (CRC Press, 2014). at <https://doi.org/10.1201/b17191-19>

60. Couvreur, P., Kante, B., Roland, M., Guiot, P., BAuduin, P. \& Speiser, P. Polycyanoacrylate nanocapsules as potential lysosomotropic carriers: preparation, morphological and sorptive properties. Journal of Pharmacy and Pharmacology 31, 331-332 (1979).

61. Coty, J.-B., Varenne, F., Vachon, J.-J. \& Vauthier, C. Serial multiple crossed immunoelectrophoresis at a microscale: A stamp-sized 2D immunoanalysis of protein C3 activation caused by nanoparticles: Proteomics and 2-DE. ELECTROPHORESIS 37, 2401-2409 (2016).

62. Laurell, C.-B. Antigen-antibody crossed electrophoresis. Analytical biochemistry 10, 358-361 (1965).

63. Mancini, G. A., Carbonara, A. t \& Heremans, J. F. Immunochemical quantitation of antigens by single radial immunodiffusion. immunochemistry 2, 235IN5-254IN6 (1965).

64. Lucy, C.A., MacDonald, A.M., Gulcev, M.D. Non-covalent capillary coatings for protein separations in capillary electrophoresis. J. Chromatogr. A. 1184, 81-105 (2008)

65. Krylov, S. N. Nonequilibrium Capillary Electrophoresis of Equilibrium Mixtures (NECEEM): A Novel Method for Biomolecular Screening. J Biomol Screen 11, 115-122 (2005).

66. Olivier, J.-C., Vauthier, C., Taverna, M., Ferrier, D. \& Couvreur, P. Preparation and characterization of biodegradable poly(isobutylcyano acrylate) nanoparticles with the surface modified by the adsorption of proteins. Colloids and Surfaces B: Biointerfaces 4, 349-356 (1995). 


\begin{tabular}{|c|c|c|c|c|c|c|}
\hline NPs & $\begin{array}{c}\text { Hydrodynamic } \\
\text { diameter } *(\mathrm{~nm})\end{array}$ & $\begin{array}{l}\text { Zeta potential } \\
\quad * *(\mathrm{mV})\end{array}$ & $\begin{array}{c}\text { Concentration } \\
* * *(\mathrm{mg} / \mathrm{mL}) \\
\end{array}$ & $\begin{array}{c}\text { Shell configuration } \\
\text { (density, length) [57-59] }\end{array}$ & $\begin{array}{c}\text { Complement activation } \\
\text { (pathway) [29-61] }\end{array}$ & $\begin{array}{c}\text { Schematic } \\
\text { representation }\end{array}$ \\
\hline $\mathbf{R 1}$ & 286 & -4 & 38 & $\begin{array}{c}\text { Dense long brush } \\
(1.3 \%, 66 \mathrm{kDa})\end{array}$ & No & \\
\hline $\mathbf{R 2}$ & 208 & -10 & 44 & $\begin{array}{c}\text { Dense short brush } \\
(1.3 \%, 17 \mathrm{kDa})\end{array}$ & Yes (Alternative) & \\
\hline R3 & 281 & -5 & 47 & $\begin{array}{l}\text { Loose long brush } \\
(0.5 \%, 66 \mathrm{kDa})\end{array}$ & $\begin{array}{c}\text { Yes (Classical, lectin and } \\
\text { alternative) }\end{array}$ & \\
\hline A1 & 88 & -5 & 37 & $\begin{array}{l}\text { Loose Loops } \\
(1.3 \%, 66 \mathrm{kDa})\end{array}$ & $\begin{array}{l}\text { Yes (Classical and } \\
\text { alternative) }\end{array}$ & \\
\hline A2 & 159 & -4 & 13 & $\begin{array}{l}\text { Tight Loops } \\
(1.3 \%, 66 \mathrm{kDa})\end{array}$ & $\begin{array}{l}\text { Yes (Classical and } \\
\text { alternative) }\end{array}$ & \\
\hline \multicolumn{7}{|c|}{ *by dynamic light scattering (DLS) ; **by electrophoretic light scattering (ELS) ; ***by gravimetry. } \\
\hline
\end{tabular}

Table 1: Characteristics of the NPs used in this study. 


\begin{tabular}{|c|c|c|c|}
\hline & Method 1: pl $<7$ & Method 2: $7<\mathrm{pl}<8$ & Method 3: $\mathrm{pl}>8$ \\
\hline \multirow{4}{*}{$\begin{array}{l}\left.1^{\circ}\right) \text { Capillary } \\
\text { conditioning }\end{array}$} & \multicolumn{3}{|c|}{ Rinse: Water $-2 \mathrm{~min}-20 \mathrm{psi}$} \\
\hline & Rinse: $\mathrm{HCl} 1 \mathrm{M}-5 \mathrm{~min}-20 \mathrm{psi}$ & \multicolumn{2}{|c|}{ Rinse: $\mathrm{NaOH} 0.1 \mathrm{M}-5 \mathrm{~min}-20 \mathrm{psi}$} \\
\hline & Rinse: Coating PEO $-5 \mathrm{~min}-20 \mathrm{psi}$ & \multicolumn{2}{|c|}{ Rinse: Coating Polybrene ${ }^{\circledast}-5 \mathrm{~min}-20 \mathrm{psi}$} \\
\hline & $\begin{array}{l}\text { Rinse: Electrolyte Phosphate } \mathrm{pH} 7.4- \\
\qquad 5 \mathrm{~min}-20 \mathrm{psi}\end{array}$ & $\begin{array}{l}\text { Rinse: Electrolyte Phosphate } \mathrm{pH} 3- \\
\qquad 5 \mathrm{~min}-20 \mathrm{psi}\end{array}$ & $\begin{array}{l}\text { Rinse: Electrolyte Phosphate } \mathrm{pH} 7.4- \\
\qquad 5 \mathrm{~min}-20 \mathrm{psi}\end{array}$ \\
\hline \multirow{2}{*}{$\begin{array}{l}\left.2^{\circ}\right) \text { Sample } \\
\text { analysis }\end{array}$} & \multicolumn{3}{|c|}{ Sample Injection: Hydrodynamic injection $-5 \mathrm{sec}-0.5 \mathrm{psi}$} \\
\hline & $\begin{array}{l}\text { Separation: Electrolyte phosphate } \mathrm{pH} \\
7.4-20 \mathrm{~min}-25 \mathrm{kV}-\text { Reverse polarity }\end{array}$ & $\begin{array}{l}\text { Separation: Electrolyte phosphate } \mathrm{pH} \\
3-20 \mathrm{~min}-20 \mathrm{kV}-\text { Reverse polarity }\end{array}$ & $\begin{array}{l}\text { Separation: Electrolyte phosphate } \mathrm{pH} \\
7.4-20 \mathrm{~min}-20 \mathrm{kV}-\text { Reverse polarity }\end{array}$ \\
\hline \multirow{3}{*}{$\begin{array}{l}\left.3^{\circ}\right) \text { Capillary } \\
\text { washing }\end{array}$} & \multicolumn{3}{|c|}{ Rinse: Water $-2 \mathrm{~min}-20 \mathrm{psi}$} \\
\hline & Rinse: $\mathrm{NaOH} 1 \mathrm{M}-3 \mathrm{~min}-20 \mathrm{psi}$ & \multicolumn{2}{|c|}{ Rinse: SDS $50 \mathrm{mM}-3 \mathrm{~min}-20 \mathrm{psi}$} \\
\hline & \multicolumn{3}{|c|}{ Rinse: Water $-2 \mathrm{~min}-20 \mathrm{psi}$} \\
\hline
\end{tabular}

Table 2: Conditions of CE methods used for protein detection with $\mathrm{pl}<7(\operatorname{method} 1), 7<\mathrm{pl}<8(\operatorname{method} 2)$ and $\mathrm{pl}>8(\operatorname{method} 3)$. 


\begin{tabular}{|c|c|c|c|c|c|c|c|c|c|c|}
\hline Protein & PDB & $\begin{array}{c}\mathrm{MW} \\
\text { (kDa) }\end{array}$ & pl & a.a number & $\begin{array}{c}\text { Dh size } \\
\text { (nm) }\end{array}$ & $\begin{array}{c}\text { Cristallographic } \\
\text { size }(\mathrm{nm})\end{array}$ & GRAVY** & $\begin{array}{c}\text { Charged } \\
\text { residues** }\end{array}$ & $\begin{array}{c}\text { Carbohydrate } \\
\% \\
\end{array}$ & $\begin{array}{c}\text { Protein shape } \\
\text { (not at scale) }\end{array}$ \\
\hline $\begin{array}{l}\text { Insulin B } \\
\text { chain }\end{array}$ & $4 \mathrm{HN}$ & 3.5 & 5.3 & 30 & $<2.7^{64}$ & $3.7 \times 2.6 \times 2.4 *$ & 0.303 & $2+; 2-$ & No & Globular \\
\hline Aprotinin & 3LDJ & 6.5 & 10.5 & 58 & $3.2^{65}$ & $3.4 \times 2.7 \times 2.7^{*}$ & -0.479 & $10+; 4-$ & No & $\begin{array}{l}\text { Globular } \\
\text { ग्जिक्तु }\end{array}$ \\
\hline Orosomucoïd & 3KQ0 & 44.1 & 2.8 & 183 & $7.3^{66}$ & $4.6 \times 4.5 \times 4.0^{*}$ & -0.764 & $22+; 30-$ & $45 \%{ }^{67}$ & Globular \\
\hline Ovalbumin & 10VA & 44.3 & 4.6 & 385 & $5.6^{68}$ & $7 \times 3.6 \times 3^{69}$ & -0.006 & $35+; 47-$ & $3.5 \%{ }^{70}$ & $\begin{array}{c}\text { Globular } \\
\text { ofse }\end{array}$ \\
\hline Transthyretin & $4 T L T$ & 55 & $4.6-4.9$ & $\begin{array}{l}508 \text { ( } 127 \times 4 \\
\text { subunits) }\end{array}$ & $8^{71}$ & $6.9 \times 5.5 \times 4.8^{*}$ & -0.274 & $12+; 17-$ & No & Ovoïd \\
\hline BSA & $4 \mathrm{~F} 5 \mathrm{~S}$ & 66.4 & 4.8 & 583 & $7.7^{72}$ & $14.1 \times 4.2 \times 4.2^{73}$ & -0.475 & $82+; 99-$ & No & Globular \\
\hline $\begin{array}{c}\text { Apo } \\
\text { Transferrin }\end{array}$ & $2 \mathrm{HAU}$ & 80 & 5.8 & 679 & $7.3^{74}$ & $7.5 \times 7.5 \times 7.4$ & -0.411 & $84+; 87-$ & $5.9 \%{ }^{75}$ & Globular \\
\hline Human IgG & $1 \mathrm{HZH}$ & 150 & $6.6-7.4$ & $\begin{array}{c}1344(457- \\
\text { heavy } 2 \\
(215-\text { light x2) }\end{array}$ & $10.6^{66}$ & $14.5 \times 8.5 \times 4^{76}$ & -0.483 & $144+; 122-$ & $3 \%{ }^{75}$ & Y - shaped \\
\hline Thyroglobulin & P01267 & 669 & 4.5 & $\begin{array}{c}5500 \text { ( } 2750 \times 2 \\
\text { subunits) }\end{array}$ & $17.2^{77}$ & n.d & -0.257 & $510+$; 592- & $10 \%^{78}$ & n.d \\
\hline
\end{tabular}

Table 3: Summary of the characteristics of tested proteins for the shield-effect study. PDB: Protein Data Bank reference, MW: Molecular weight, pl: isoelectrical point, a.a number: number of amino acids in the protein sequence, Dh size: Hydrodynamic diameter, GRAVY: Hydrophaticity, n.d: not determined. *determined with Jmol ** determined via Expasy Protparam tool. 


\section{Legends of figures}

Figure 1: Precision and principles of separation of NPs and free proteins by the developed CE methods. A: Electrophoregrams obtained for negatively charged proteins at $\mathrm{pH} 7.4$ (Method 1 - left) and positively charged proteins (methods 2 and 3 -right). Peak 1: migration marker, peak 2: protein, peak 3: NPs. B: Principle of separation of the mixture free proteins/ NPs according to the capillary coating. C: Explanation of migration behavior taking into account electrophoretic mobility $\left(\mu_{\mathrm{EP}}\right)$ and electroosmotic mobility $\left(\mu_{\mathrm{EO}}\right)$. D: Performance of the methods in terms of linearity, intermediate precision and repeatability.

Figure 2: Adsorption trends for BSA and IgG adsorption onto the five NPs evaluated by CE (left part), rocket IE (upper right) and radial ID (lower right).

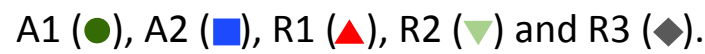

Figure 3: Shield-effect study: A- \% of adsorption of the 9 tested proteins on the five type of NPs. B- Heatmap representation of protein adsorption on the five types of NPs (White: $0 \%$ to dark blue: $100 \%$ of protein adsorbed).

Figure 4: Shield effect study: A- \% of repellent capacity of NPs after incubation with the different proteins. B- Heatmap representation of NPs repellent capacity after incubation with the different proteins (White: low RC (0\%) to dark red: high RC (100\%)).

Figure 5: Principal component analysis of protein adsorption data obtained from the analysis of 9 proteins on the 5 model NPs. A: Explained variance of principal components. B: biplot of NPs score and factors loadings according to PC1 and PC2. 
Figure 1

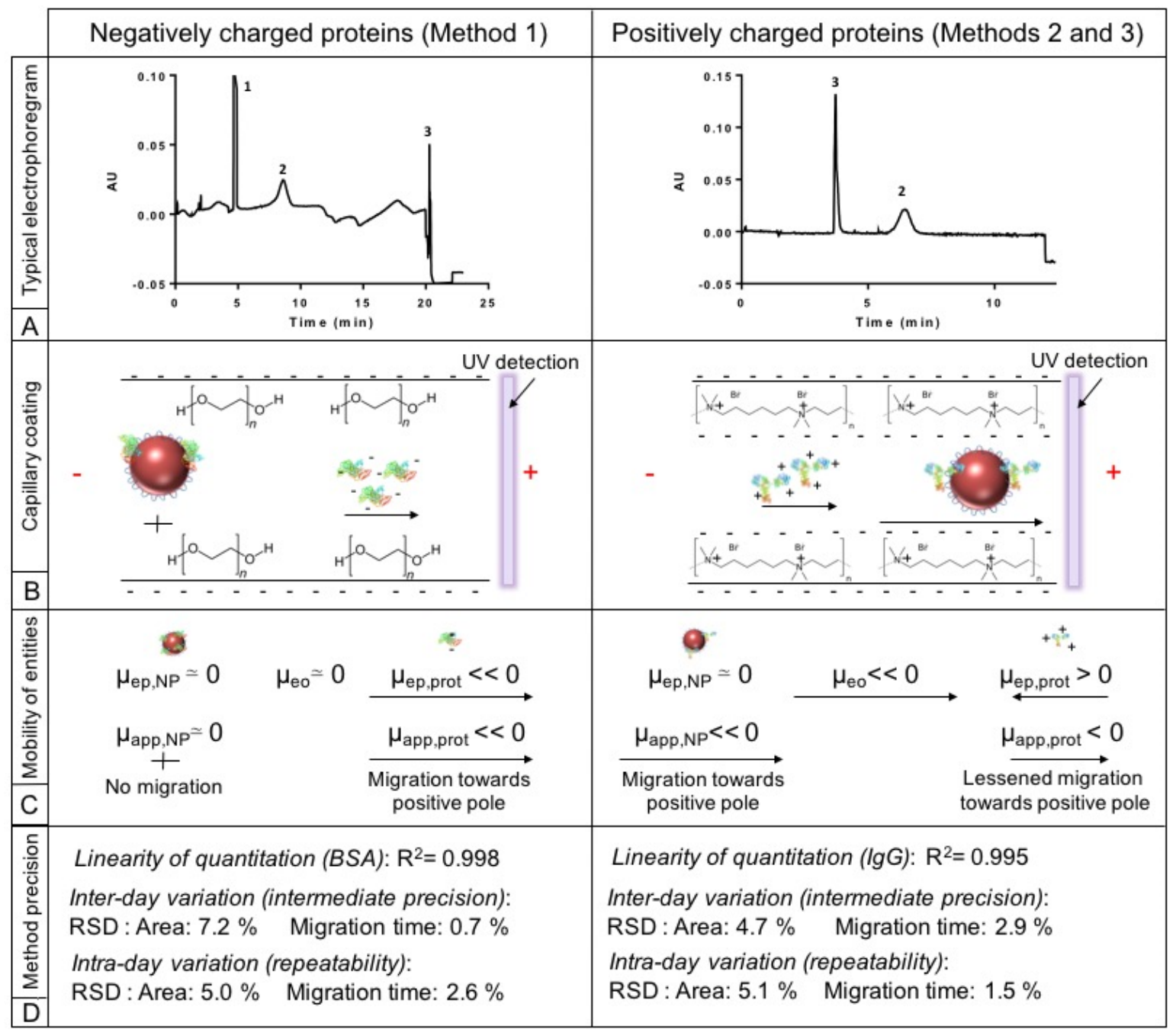


Figure 2

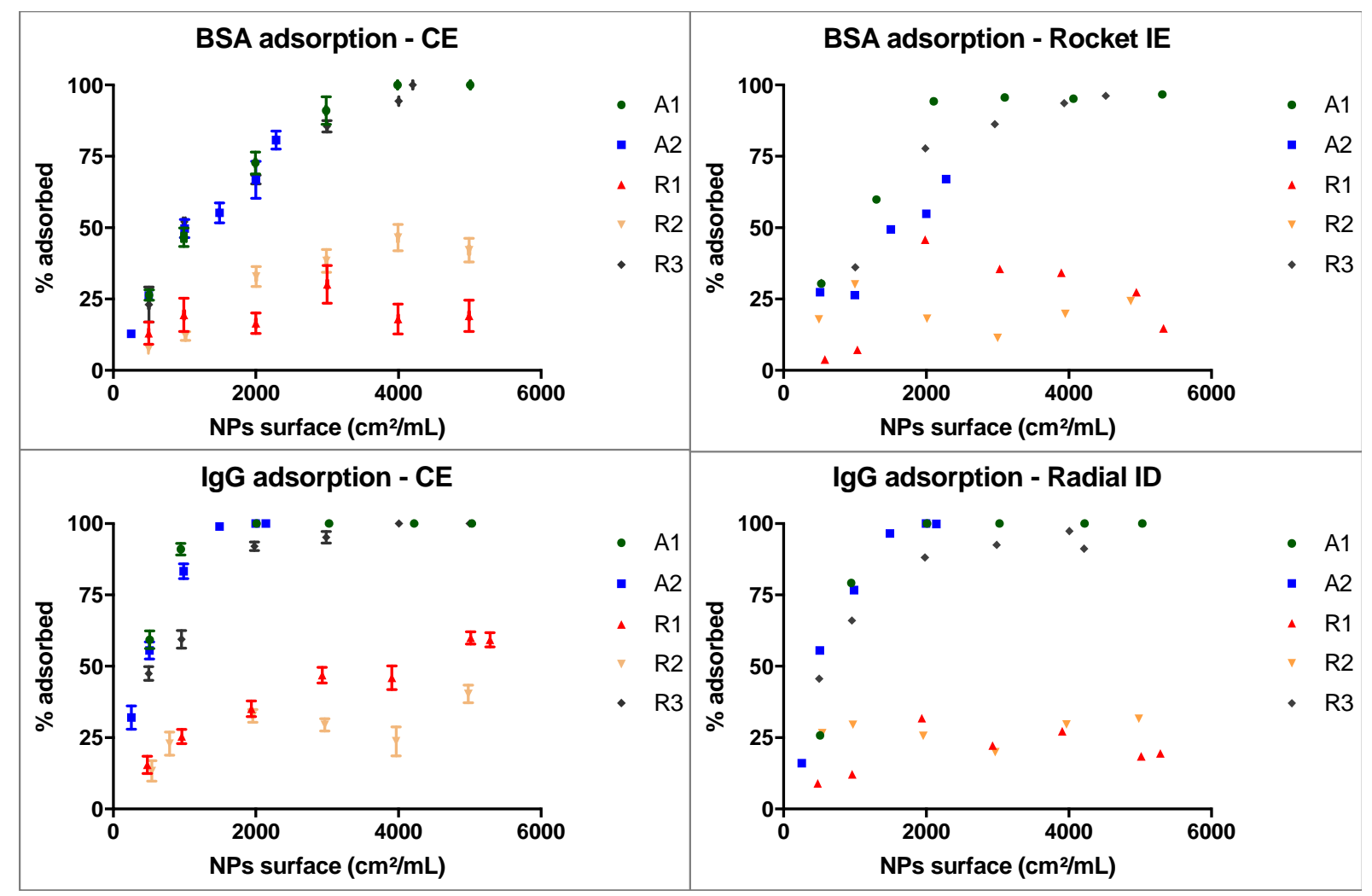


Figure 3

A

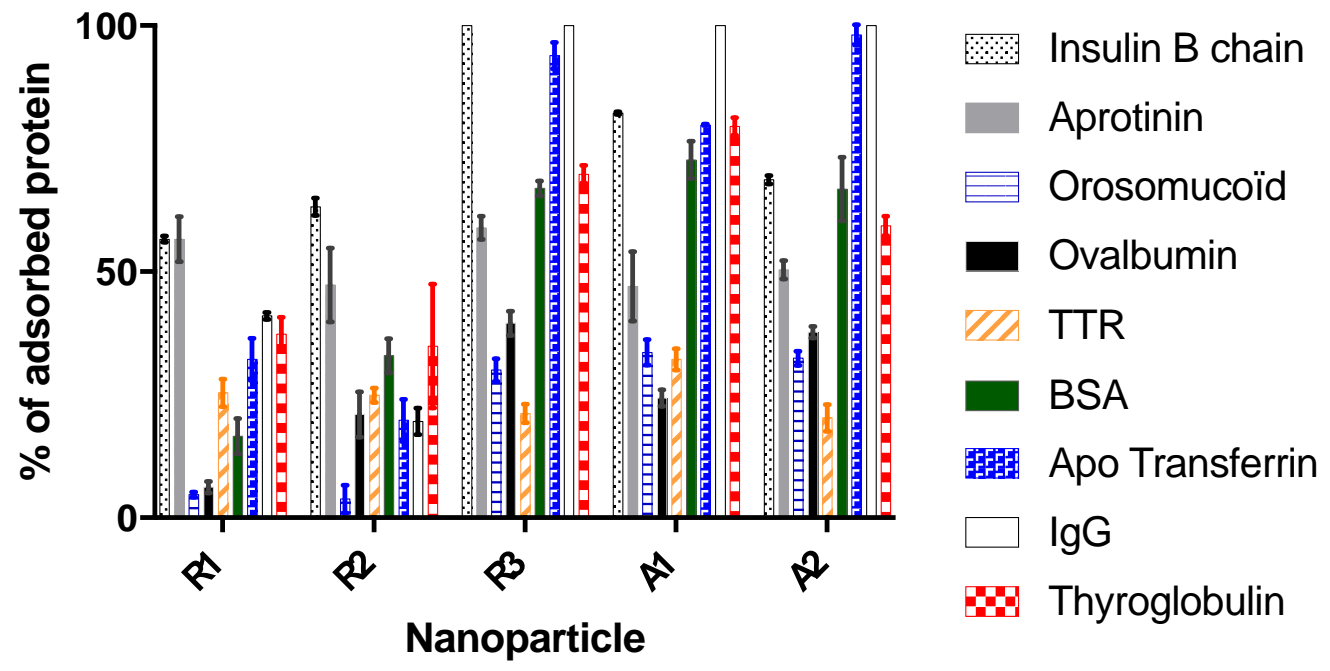

B

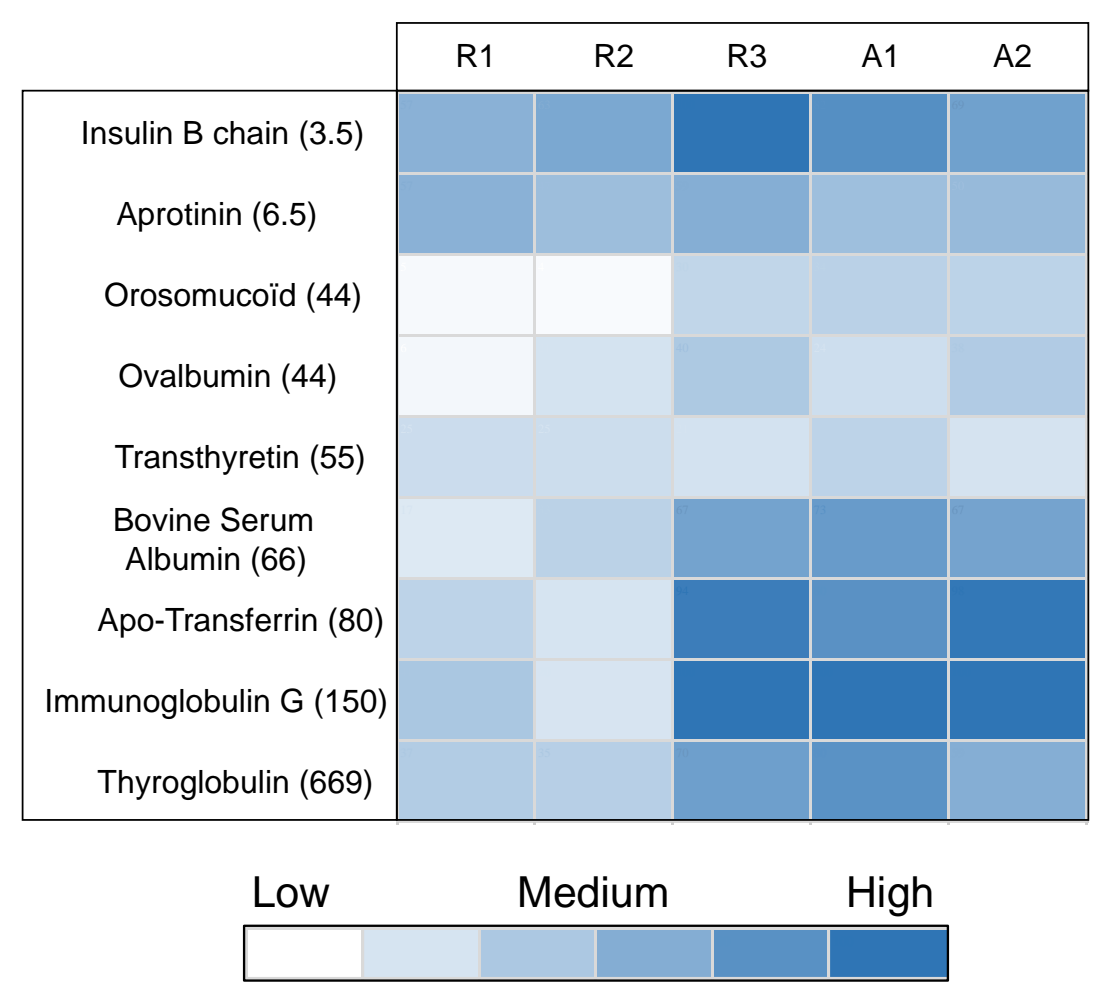

Protein adsorption heatmap 
Figure 4

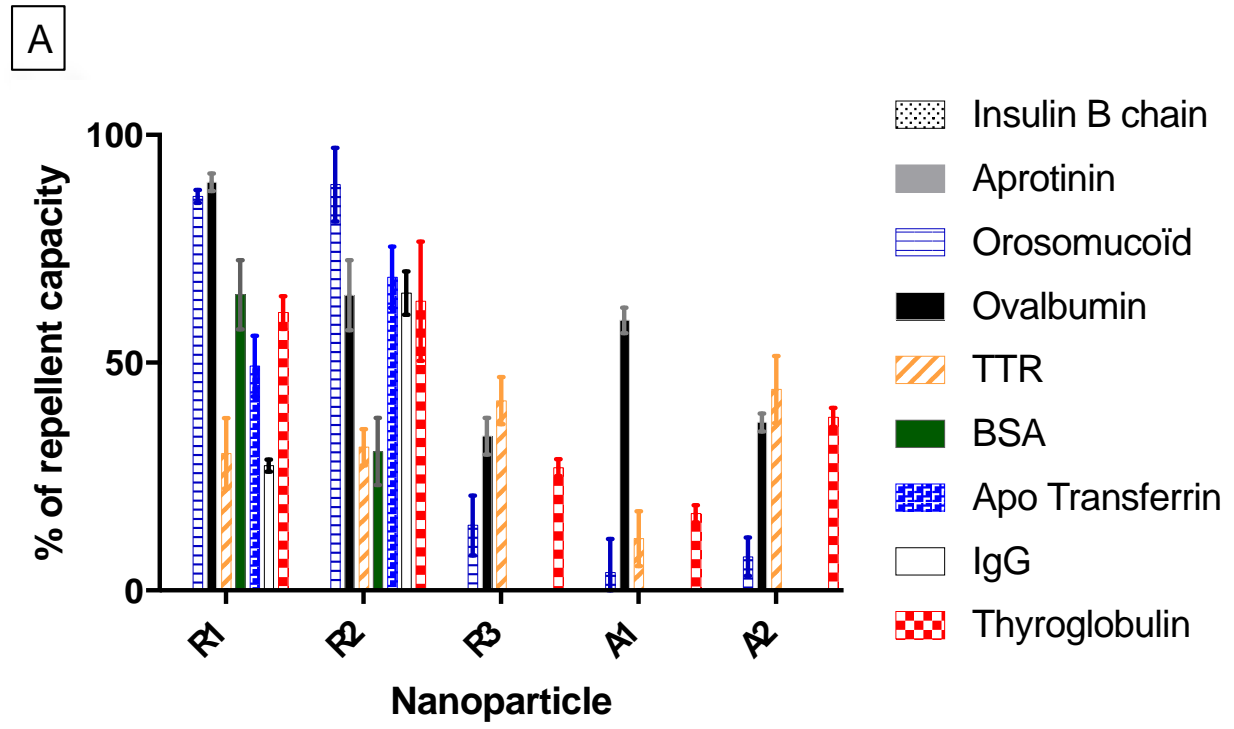

B

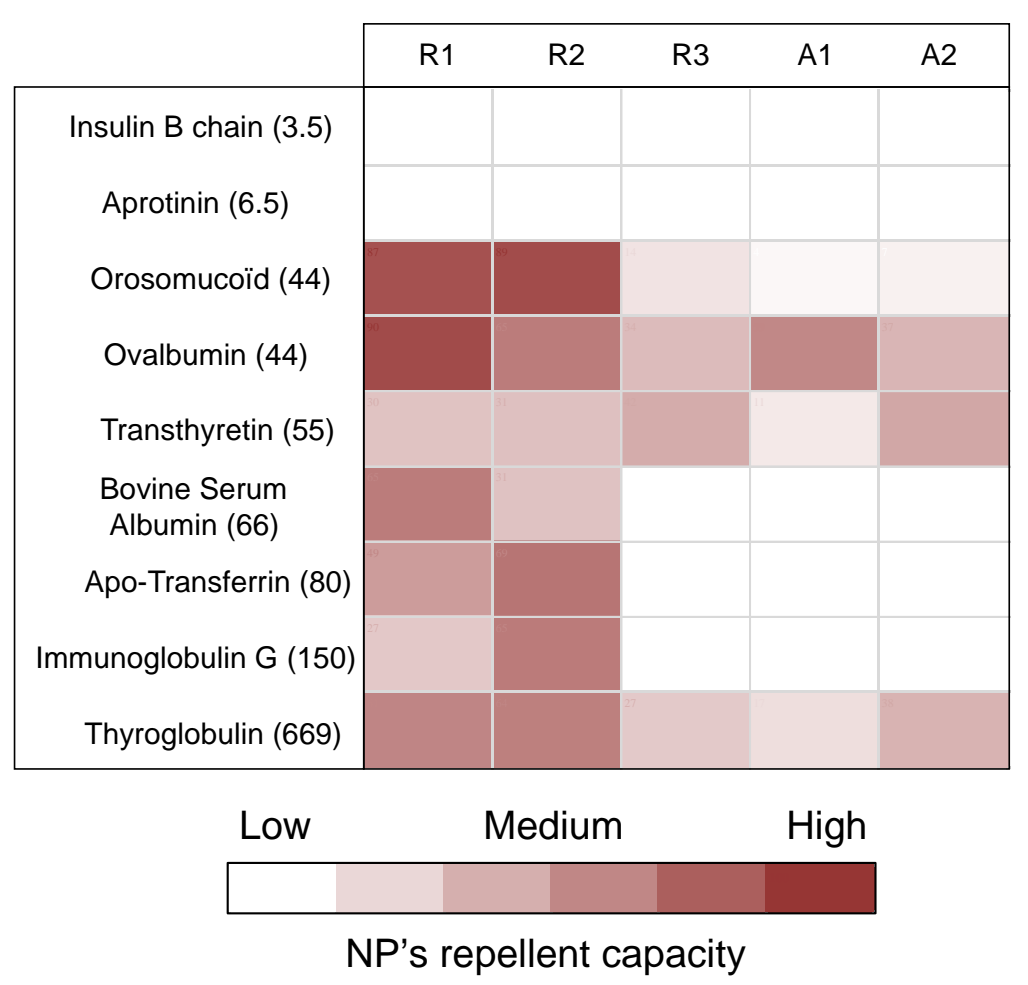


Figure 5
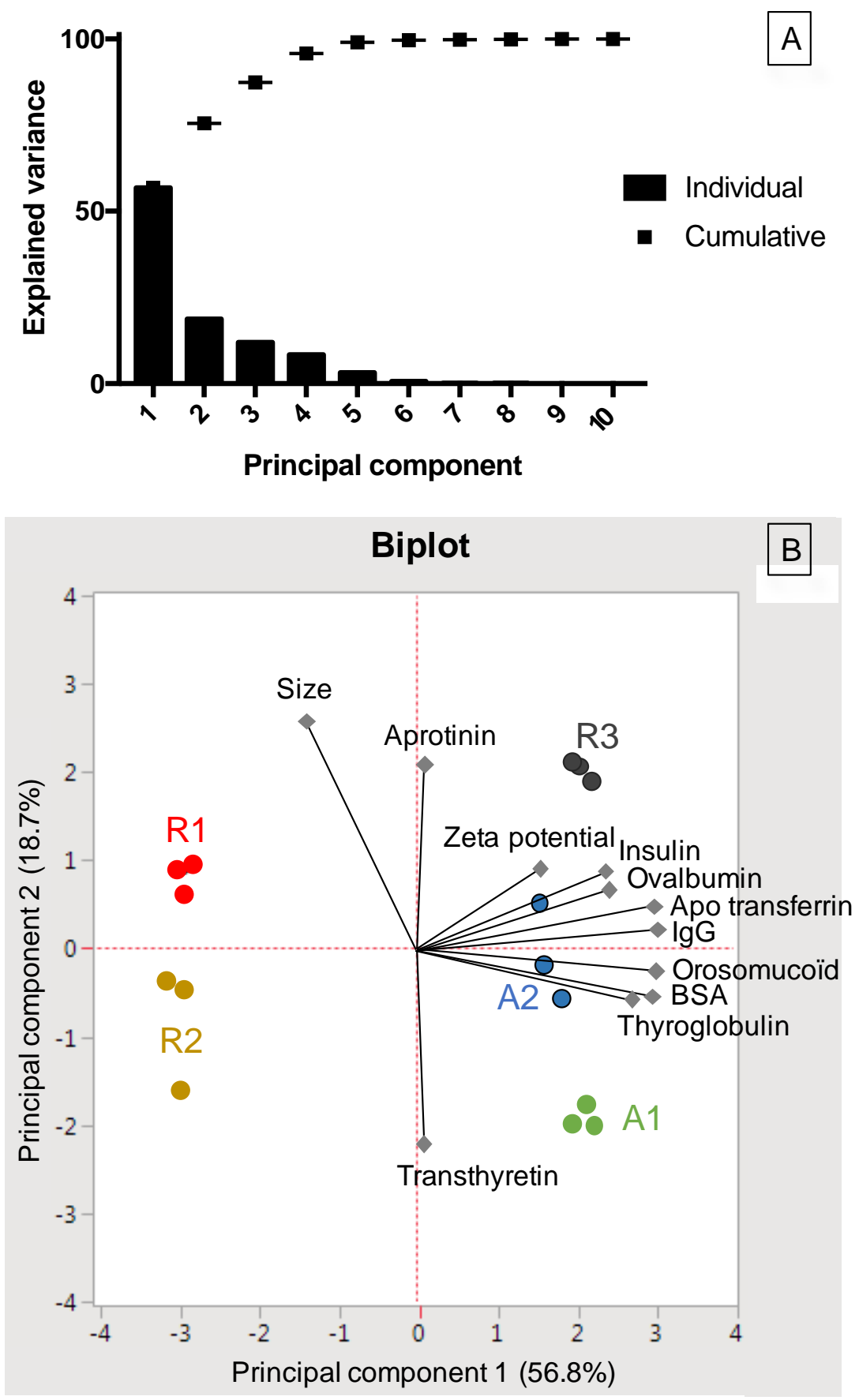


\section{Supplementary information}

\section{Characterization of nanomedicines' surface coverage using molecular probes and capillary electrophoresis}

J-B. Coty ${ }^{a}$, F. Varenne ${ }^{a}$, A. Benmalek ${ }^{b}$, O. Garsaa ${ }^{a}$, I. Le Potiera, M. Taverna ${ }^{a}$, C. Smadja ${ }^{a}$, C. Vauthier ${ }^{\mathrm{a} *}$

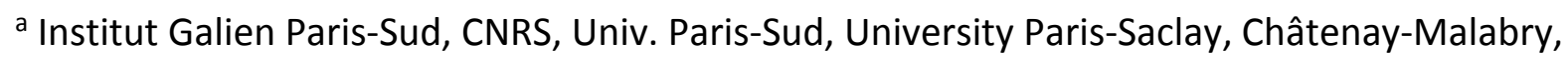
France.

${ }^{b}$ Faculty of Pharmacy, University Paris-Sud, Chatenay-Malabry France

*Correspondence: Dr. Christine Vauthier, CNRS UMR 8612, Institut Galien Paris Sud, Univ. Paris-Sud, Université Paris-Saclay, 5, rue Jean-Baptiste Clément, 92296 Châtenay-Malabry, France. Fax: +33 146835946. E-mail: christine.vauthier@u-psud.fr 


\section{S1: Determination of BSA adsorption on NP A1 via rocket immunoelectrophoresis}
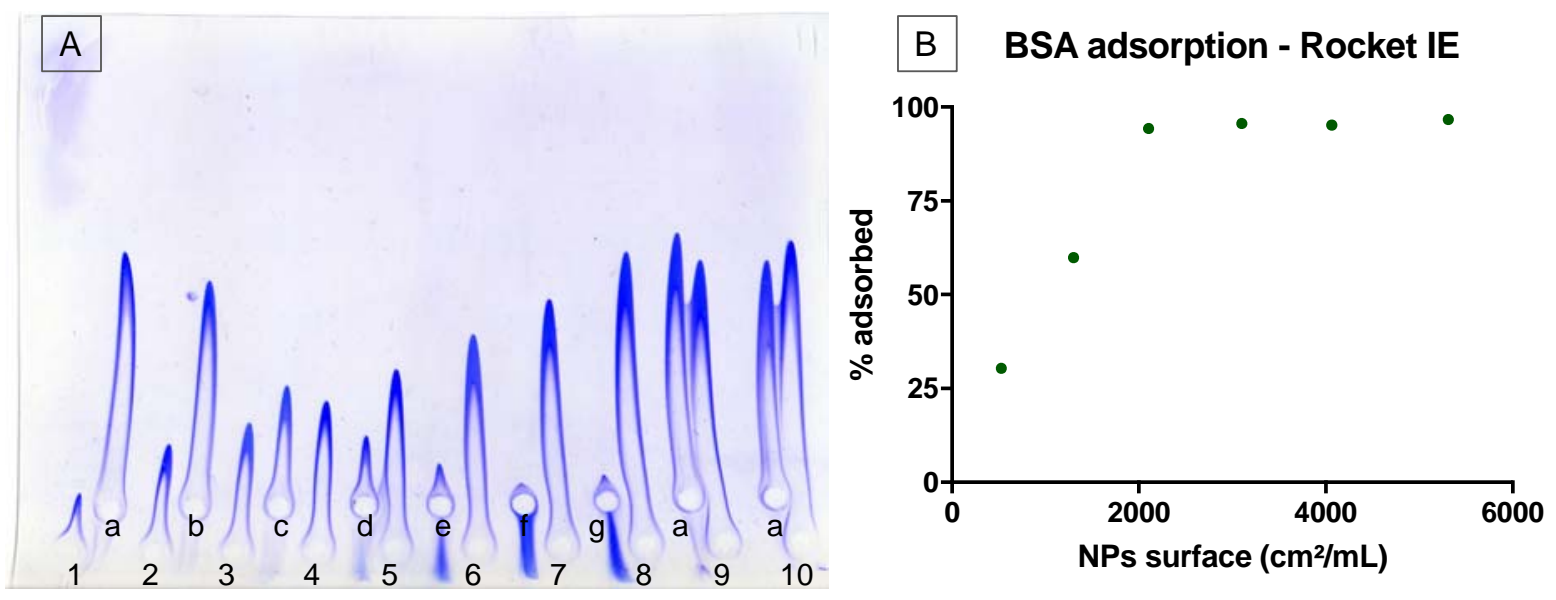

Figure S1: (A) Rocket immunoelectrophoresis gel of BSA adsorption onto nanoparticle A1. 1-10 represents the calibration samples of BSA: $25 \mu \mathrm{g} / \mathrm{mL}$ (1), $50 \mu \mathrm{g} / \mathrm{mL}$ (2), $75 \mu \mathrm{g} / \mathrm{mL}$ (3), $100 \mu \mathrm{g} / \mathrm{mL}$ (4), $125 \mu \mathrm{g} / \mathrm{mL}$ (5), $150 \mu \mathrm{g} / \mathrm{mL}$ (6), $175 \mu \mathrm{g} / \mathrm{mL}$ (7), $200 \mu \mathrm{g} / \mathrm{mL}$ (8), $225 \mu \mathrm{g} / \mathrm{mL}$ (9), $250 \mu \mathrm{g} / \mathrm{mL}(10)$.

a-g represents the free BSA remaining after incubation with $\mathrm{A} 1$ at different surface concentrations: $500 \mathrm{~cm}^{2} / \mathrm{mL}$ (a), $1000 \mathrm{~cm}^{2} / \mathrm{mL}$ (b), $2000 \mathrm{~cm}^{2} / \mathrm{mL}$ (c), $3000 \mathrm{~cm}^{2} / \mathrm{mL}$ (d), 4000 $\mathrm{cm}^{2} / \mathrm{mL}$ (e), $5000 \mathrm{~cm}^{2} / \mathrm{mL}$ (f), $6000 \mathrm{~cm}^{2} / \mathrm{mL}$ (g).

(B) Corresponding trend of adsorption of BSA on nanoparticle A1. 


\section{S2: Determination of IgG adsorption on NP R2 via radial immunodiffusion}

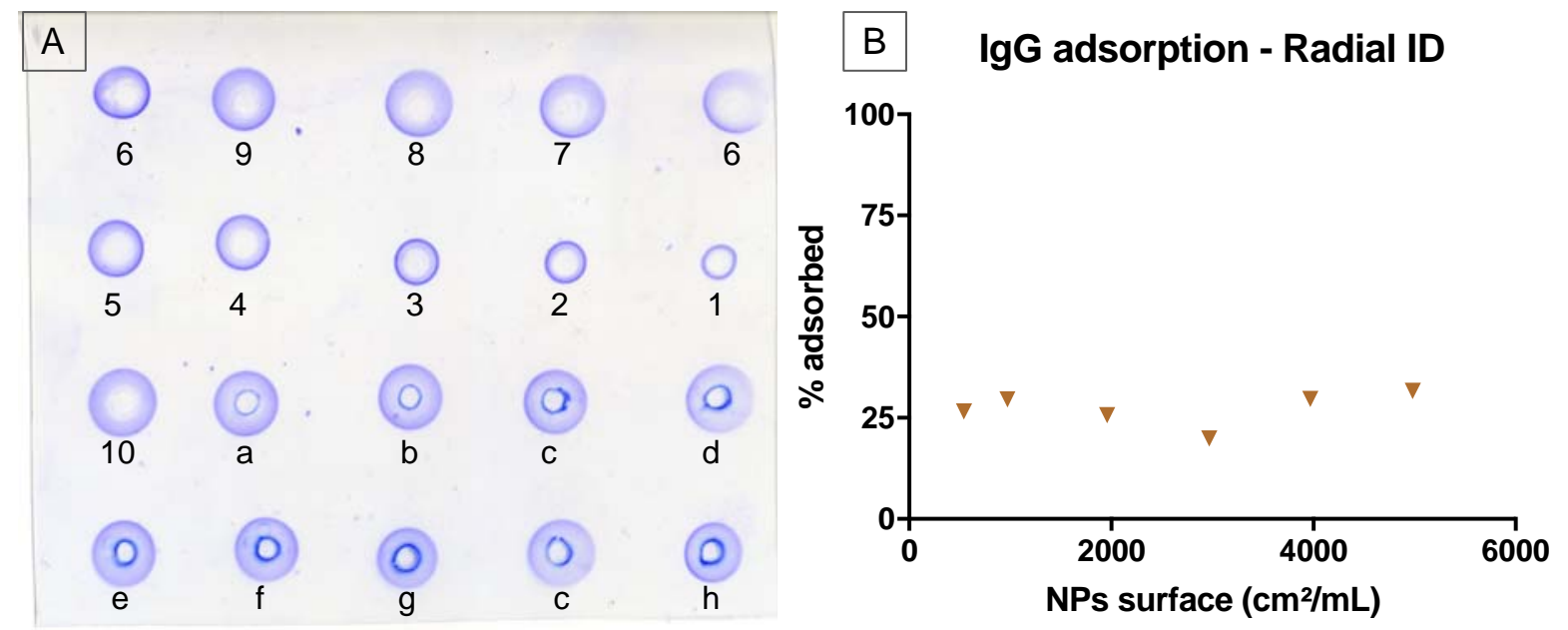

Figure S2: (A) Radial immunodiffusion gel of IgG adsorption onto nanoparticle R2.

1-10 represents the calibration samples of IgG: $25 \mu \mathrm{g} / \mathrm{mL}$ (1), $50 \mu \mathrm{g} / \mathrm{mL}$ (2), $75 \mu \mathrm{g} / \mathrm{mL}$ (3), $100 \mu \mathrm{g} / \mathrm{mL}$ (4), $125 \mu \mathrm{g} / \mathrm{mL}$ (5), $150 \mu \mathrm{g} / \mathrm{mL}$ (6), $175 \mu \mathrm{g} / \mathrm{mL}$ (7), $200 \mu \mathrm{g} / \mathrm{mL}$ (8), $225 \mu \mathrm{g} / \mathrm{mL}$ (9), $250 \mu \mathrm{g} / \mathrm{mL}(10)$.

a-g represents the free IgG remaining after incubation with $\mathrm{R} 2$ at different surface concentrations: $500 \mathrm{~cm}^{2} / \mathrm{mL}$ (a), $1000 \mathrm{~cm}^{2} / \mathrm{mL}$ (b), $2000 \mathrm{~cm}^{2} / \mathrm{mL}$ (c), $3000 \mathrm{~cm}^{2} / \mathrm{mL}$ (d), 4000 $\mathrm{cm}^{2} / \mathrm{mL}$ (e), $5000 \mathrm{~cm}^{2} / \mathrm{mL}$ (f), $6000 \mathrm{~cm}^{2} / \mathrm{mL}$ (g).

(B) Corresponding trend of adsorption of IgG on nanoparticle R2. 


\section{S3: Verification of the absence of aggregates upon NP-proteins incubation}

Sample

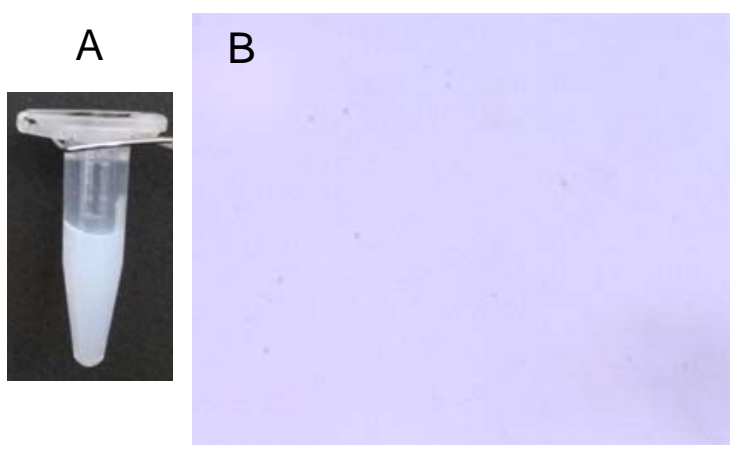

Size Distroution by Intensity
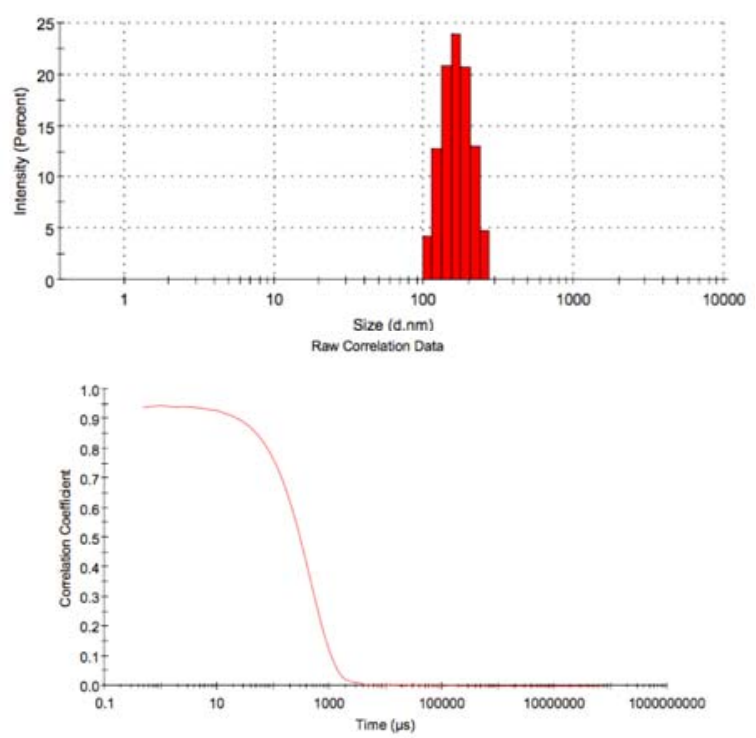

Positive aggregation control

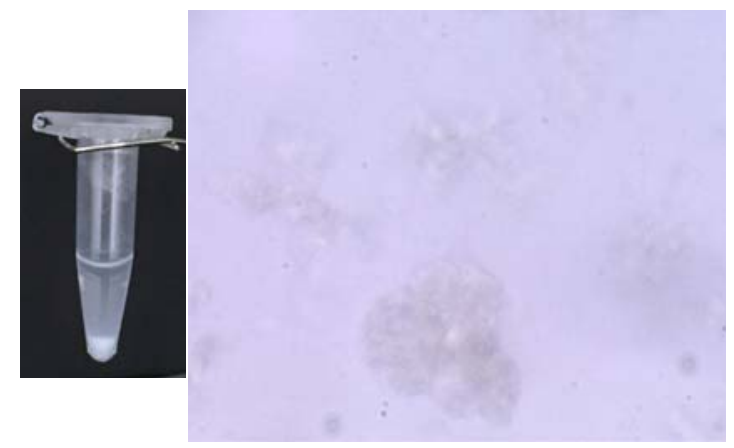

Size Distribution by Intensity

C

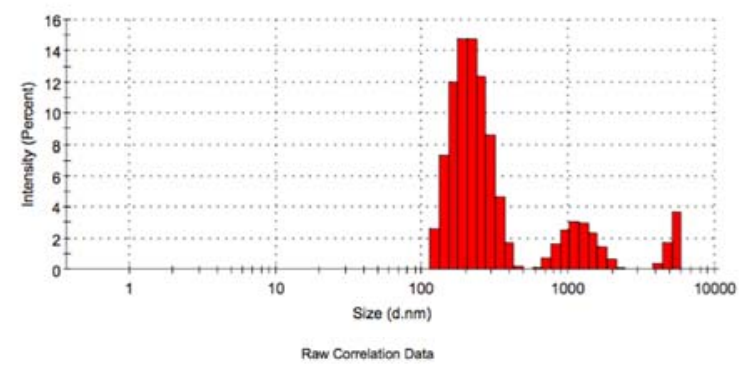

D

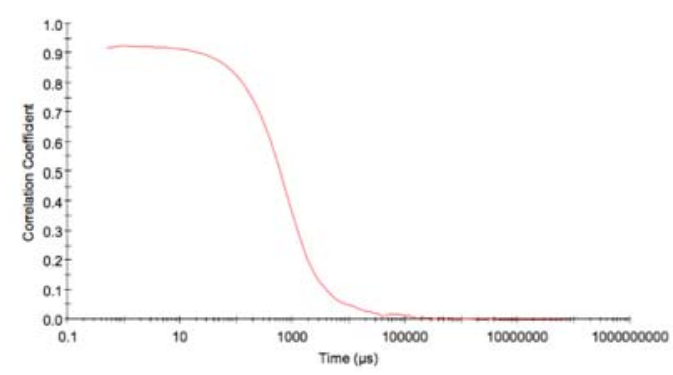

Figure S3: example of aggregation control made on NP A2 after incubation with ApoTransferrin (left part) compared to a positive control of an aggregated sample of A2 after incubation with fibrinogen (right part).
(A) Verification of the absence of visible aggregates
(B) Optical microscopic verification of the absence of aggregates
(C) Measurement of NP size by dynamic light scattering (DLS)
(D) Autocorrelation curve of DLS measurement 


\section{S4: Data of characterization and adsorption for PCA}

\begin{tabular}{|c|c|c|c|c|c|c|c|c|c|c|c|}
\hline \multirow[b]{2}{*}{ Nanoparticle } & \multirow[b]{2}{*}{ Size $(\mathrm{nm})$} & \multirow[b]{2}{*}{ Zeta potential $(\mathrm{mV})$} & \multicolumn{9}{|c|}{ Adsorption \% of protein probes on NPs } \\
\hline & & & Insulin B chain & Aprotinin & Orosomucoïd & Ovalbumin & Tranthyretin & BSA & Apo-Transferrin & $\lg G$ & Thyroglobulin \\
\hline \multirow{3}{*}{ R1 } & \multirow{3}{*}{286} & \multirow{3}{*}{-4} & 57.23 & 53.25 & 5.42 & 4.63 & 24.45 & 20.5 & 29.21 & 40.42 & 39.63 \\
\hline & & & 56.52 & 61.8 & 4.77 & 7.64 & 28.58 & 15.8 & 35.2 & 41.87 & 36.36 \\
\hline & & & 55.94 & 54.72 & 5.74 & 6.27 & 23.21 & 13.3 & 29.91 & 40.8 & 43.21 \\
\hline \multirow{3}{*}{ R2 } & \multirow{3}{*}{208} & \multirow{3}{*}{-10} & 64.14 & 53.47 & 2.52 & 24.72 & 26 & 35.4 & 16.21 & 20.68 & 24.28 \\
\hline & & & 61.21 & 49.63 & 7.68 & 22.17 & 23.24 & 30.4 & 24.55 & 21.53 & 31.69 \\
\hline & & & 64.33 & 38.93 & 3.04 & 15.23 & 25.33 & 32.9 & 18.61 & 16.51 & 48.75 \\
\hline \multirow{3}{*}{ R3 } & \multirow{3}{*}{281} & \multirow{3}{*}{-5} & 100 & 57.91 & 32.02 & 40.86 & 21.26 & 65.8 & 92.46 & 100 & 70.56 \\
\hline & & & 100 & 61.62 & 29.09 & 40.93 & 23.08 & 66.3 & 92.36 & 100 & 67.3 \\
\hline & & & 100 & 57.3 & 27.5 & 36.68 & 19.34 & 68.6 & 96.99 & 100 & 70.08 \\
\hline \multirow{3}{*}{ A1 } & \multirow{3}{*}{88} & \multirow{3}{*}{-5} & 81.98 & 52.02 & 35.8 & 25.17 & 34.3 & 76.4 & 79.98 & 100 & 80.12 \\
\hline & & & 82.3 & 48.75 & 30.79 & 25.39 & 32.33 & 68.7 & 79.72 & 100 & 79.98 \\
\hline & & & 82.44 & 49.03 & 34.3 & 22.39 & 29.95 & 73 & 79.85 & 100 & 83.19 \\
\hline \multirow{3}{*}{ A2 } & \multirow{3}{*}{159} & \multirow{3}{*}{-4} & 69.11 & 54.94 & 32.52 & 36.54 & 21.64 & 62.5 & 96.04 & 100 & 54.93 \\
\hline & & & 68.38 & 41.45 & 32.27 & 37.96 & 19 & 62.1 & 97.24 & 100 & 58.6 \\
\hline & & & 67.46 & 44.62 & 34.94 & 38.73 & 24.38 & 71.4 & 100 & 100 & 55.5 \\
\hline
\end{tabular}

Table S4: Data used for principal component analysis. Values of hydrodynamic diameter $(\mathrm{nm})$ and zeta potential of the five NPs. Values of adsorption of the nine protein probes on the five NPs made in triplicate. 